\title{
Serotonin-related rodent models of early-life exposure relevant for neurodevelopmental vulnerability to psychiatric disorders
}

\author{
Tamara S. Adjimann', Carla V. Argañaraz ${ }^{1}$ and Mariano Soiza-Reilly [1'
}

\begin{abstract}
Mental disorders including depression and anxiety are continuously rising their prevalence across the globe. Early-life experience of individuals emerges as a main risk factor contributing to the developmental vulnerability to psychiatric disorders. That is, perturbing environmental conditions during neurodevelopmental stages can have detrimental effects on adult mood and emotional responses. However, the possible maladaptive neural mechanisms contributing to such psychopathological phenomenon still remain poorly understood. In this review, we explore preclinical rodent models of developmental vulnerability to psychiatric disorders, focusing on the impact of early-life environmental perturbations on behavioral aspects relevant to stress-related and psychiatric disorders. We limit our analysis to wellestablished models in which alterations in the serotonin (5-HT) system appear to have a crucial role in the pathophysiological mechanisms. We analyze long-term behavioral outcomes produced by early-life exposures to stress and psychotropic drugs such as the selective 5-HT reuptake inhibitor (SSRI) antidepressants or the anticonvulsant valproic acid (VPA). We perform a comparative analysis, identifying differences and commonalities in the behavioral effects produced in these models. Furthermore, this review discusses recent advances on neurodevelopmental substrates engaged in these behavioral effects, emphasizing the possible existence of maladaptive mechanisms that could be shared by the different models.
\end{abstract}

\section{Introduction}

Mental disorders including depression and anxiety are devastating and disabling conditions for the individual's life, with an extremely concerning high prevalence worldwide. Currently, around $4.4 \%$ and $3.6 \%$ of the global population suffers from depressive and anxiety disorders, respectively, while the burden of mental illnesses is continuously rising ${ }^{1,2}$.

Psychiatric disorders arise from a complex combination of genetic, biological, environmental, and psychosocial factors. However, one of the main risk factors

Correspondence: Mariano Soiza-Reilly (msoizareilly@fbmc.fcen.uba.ar) ${ }^{1}$ Instituto de Fisiología, Biología Molecular y Neurociencias (IFIBYNE), Consejo Nacional de Investigaciones Científicas y Técnicas (CONICET), Facultad de Ciencias Exactas y Naturales, Universidad de Buenos Aires, Buenos Aires, Argentina

These authors contributed equally: Tamara S. Adjimann, Carla V. Argañaraz contributing to psychopathology corresponds to early-life adverse experiences during childhood, especially those involving traumatic or stressful events, such as maltreatment, abuse, poor or neglectful parenting, and loss of a family member, among others ${ }^{3-7}$. Furthermore, adverse experiences not only could contribute to pathological mental states, but may also affect the effectiveness of prospective therapeutic treatments $\mathrm{s}^{7,8}$.

Brain imaging studies have shown that childhood maltreatment results in persistent alterations in a wide repertoire of neurocognitive systems involved in threat processing, reward, emotions, and executive control ${ }^{6,8,9}$. Interestingly, such alterations can often be found even in the absence of psychiatric conditions, indicating that maladaptive mechanisms produced by adverse environments in the early-life could predispose to latent vulnerabilities to future psychiatric disorders ${ }^{8,9}$.

\section{(c) The Author(s) 2021}

(c) (i) Open Access This article is licensed under a Creative Commons Attribution 4.0 International License, which permits use, sharing, adaptation, distribution and reproduction c. in any medium or format, as long as you give appropriate credit to the original author(s) and the source, provide a link to the Creative Commons license, and indicate if changes were made. The images or other third party material in this article are included in the article's Creative Commons license, unless indicated otherwise in a credit line to the material. If material is not included in the article's Creative Commons license and your intended use is not permitted by statutory regulation or exceeds the permitted use, you will need to obtain permission directly from the copyright holder. To view a copy of this license, visit http://creativecommons.org/licenses/by/4.0/. 
Early-life exposure to certain drugs that interfere with the normal neurodevelopmental trajectories could also increase the predisposition of individuals to develop psychiatric disorders ${ }^{10-13}$. In particular, chemical substances that can interfere with crucial molecular and cellular neurodevelopmental events (e.g., cell proliferation, migration, differentiation, axon growth, synaptic connectivity, etc...) during the so-called critical periods ${ }^{14-}$ 16. These critical periods could represent unique developmental windows of brain plasticity, particularly relevant for preventive or therapeutic interventions ${ }^{16-18}$.

One example of this, is the use of antidepressant drugs that act as selective serotonin (5-HT) reuptake inhibitors (SSRIs) in pregnant and lactating depressed mothers ${ }^{19,20}$. These molecules have as a main molecular target the 5HT transporter (SERT) typically present at the axon terminals of 5-HT neurons. Accumulating clinical evidence indicates that perinatal exposure to SSRIs could have a detrimental impact on infant's neurodevelopment, with long-lasting consequences on cognitive and emotional capabilities ${ }^{19-26}$. In addition, other lines of evidence indicate that early exposure to SSRIs during pregnancy could increase the risk of Autism Spectrum Disorders $(\mathrm{ASD})^{27-32}$, which in turn present a robust comorbidity with other psychiatric disorders including anxiety and depression $^{33,34}$. However, there is a general agreement that adverse consequences observed after antenatal SSRI treatments should be always contrasted against the highly detrimental consequences of the unmedicated maternal mental illness.

To investigate the impact of early-life adverse experiences and exposure to drugs that could interfere with the normal neurodevelopment, several preclinical rodent models were developed, in which many of the emotional, social and cognitive aspects of human psychopathology can be recapitulated ${ }^{10,12,35-40}$. These models represent very useful tools to interrogate different aspects of the highly complex human pathophysiology, likely implying dysregulation of neurotransmitter systems, hormones and neuromodulators, growth factors, immune and inflammatory molecules, etc... ${ }^{3,6,7,35,36}$. In addition, brain structures such as prefrontal and sensory cortical regions, as well as other limbic regions including the amygdala, hippocampus and brainstem nuclei, have been increasingly driving the attention of clinicians and researchers as plausible neurodevelopmental substrates contributing to the vulnerability to mental illness $3,6,35,36,41$.

In this review, we explore well-established rodent models applied to study the impact of early-life environmental perturbations on adult behaviors of relevance to psychiatric disorders. We limited our analysis to models in which alterations in the 5-HT neurotransmission system appear to play a crucial role in the pathophysiological mechanisms ${ }^{42-44}$. Thus, we perform a comparative analysis across models of early-life exposures to stress and psychotropic drugs such as SSRIs or valproic acid (VPA), identifying differences and commonalities in their emotional and social behavioral outcomes, but also considering the impact of the perinatal period of exposure and treatment schedule on these effects. Importantly, this review discusses recent advances on developmental neural substrates engaged in such behavioral outcomes, also identifying possible maladaptive mechanisms likely shared by these models. To this aim, we carry out an exhaustive search in the PubMed database until February 2021, using a combination of the following key words: SSRI, fluoxetine, citalopram, serotonin, stress, early-life adversity, maternal separation, restrain, limited bedding/nesting, valproate, VPA, prenatal, gestational, pregnancy, postnatal, lactation, critical period, rodent, rat, mouse, emotional behavior, anxiety, depression, and mood. The results of this search were further refined and narrowed down to obtain only those studies that had sufficient methodological details to allow comparative analyses across the different models, as well as studies investigating the possible neurodevelopmental mechanisms contributing to the emotional and social behavioral effects.

\section{Early-life stress models: behavioral outcomes}

In consonance with the primordial role of the early-life adverse experiences in the etiology of psychiatric disorders, several rodent models were established in which the dams and/or the offspring are exposed to different stressful stimuli during different neurodevelopmental stages. Importantly, in these models many of the emotional and cognitive impairments present in the human psychopathology can be consistently replicated ${ }^{5,35,36}$.

\section{Gestational stress: restraint, unpredictable stress}

Two of the more frequently applied stressors to dams during the gestation are the restraint and unpredictable stress protocols. While the first one implies the physical body restraint of the dams in a closed compartment for time periods ranging from 1.5 to $6 \mathrm{~h}$ per day, in the second one, dams are daily subjected to a variety of different stressful stimuli including exposure to anxiogenic environments (social defeat paradigm), foot shocks (learned helplessness paradigm), forced swim, among others. Besides, these models vary according to whether the stress protocol is applied during the entire gestational period (i.e., until the offspring birth) or selectively during defined gestational windows, often resulting in distinctive behavioral outcomes.

Daily application of restraint or unpredictable stress protocols during almost the entire gestational period, in various rat and mouse strains, produces several stressrelated and emotional alterations in the offspring later in life (Table 1 ). One of the most consistently reproduced 
Table 1 Early-life stress rodent models.

\begin{tabular}{|c|c|c|c|c|}
\hline Stress type & Exposure period & Rodent model & Behavioral phenotypes & References \\
\hline $\begin{array}{l}\text { Restraint } \\
\text { (6 h/day) }\end{array}$ & G5.5-G17.5 & ICR mice & $\begin{array}{l}\downarrow \text { Rearing and Locomotion (OF) } \\
\downarrow \text { Time and Entries in open arms (EPM) } \\
\downarrow \text { Rearing and Head dipping (Hole-board test) }\end{array}$ & Miyagawa et al. ${ }^{46,47}$ \\
\hline $\begin{array}{l}\text { Restraint } \\
(2.25 \mathrm{~h} / \text { day })\end{array}$ & G7-PO & Swiss albino ND4 mice & $\begin{array}{l}\downarrow \text { Time and Entries in open arms (EPM) } \\
\uparrow \text { Time in dark compartment (Light-dark test) } \\
\uparrow \text { Alcohol consumption (2-bottle free choice) }\end{array}$ & Dong et al. ${ }^{48}$ \\
\hline Restraint ( 2.25 h/day) & G12-G18 & C57BL/6NCr mice & $\begin{array}{l}\downarrow \text { Time in open arms (EPM) } \\
=\text { No effects (MWM) }\end{array}$ & Akatsu et al. ${ }^{55}$ \\
\hline $\begin{array}{l}\text { Restraint } \\
(2.25 \mathrm{~h} / \text { day })\end{array}$ & G15-P0 & Swiss albino mice & $\begin{array}{l}\uparrow \text { Exploration and locomotion (T-maze, Tight- } \\
\text { rope) (in males) } \\
\uparrow \text { Entries in open arms (EPM) (in females) }\end{array}$ & Pallarés et al..$^{51}$ \\
\hline $\begin{array}{l}\text { Restraint } \\
\text { (1.5 h/day) }\end{array}$ & G5-G19 & $\begin{array}{l}\text { Wistar and Lewis rats NMRI } \\
\text { and C57BL/ } 6 \text { mice }\end{array}$ & $\begin{array}{l}=\text { No effects (OF) } \\
\downarrow \text { Sucrose preference (SPT) and } \uparrow \text { Latency to } \\
\text { feed (NSF) } \\
\uparrow \text { Immobility time (TST, FST) }\end{array}$ & Enayati et al. ${ }^{49}$ \\
\hline $\begin{array}{l}\text { Restraint } \\
(2.25 \mathrm{~h} / \text { day })\end{array}$ & G14-G21 & $\begin{array}{l}\text { CD rats } \\
\text { Sprague-Dawley rats }\end{array}$ & $\begin{array}{l}\downarrow \text { Entries in open arms (EPM) (in females) } \\
\downarrow \text { Time in open arms (EZM) (in males) }\end{array}$ & $\begin{array}{l}\text { Richardson et al. }{ }^{50} \\
\text { Van den Hove et al. }{ }^{54}\end{array}$ \\
\hline $\begin{array}{l}\text { Restraint } \\
(2.25 \mathrm{~h} / \text { day })\end{array}$ & G11-P0 & Sprague-Dawley rats & $\begin{array}{l}\downarrow \text { Time in the center (OF) } \\
\downarrow \text { or } \uparrow \text { Time in open arms (EPM) (in males or } \\
\text { females) } \\
\uparrow \text { Spatial learning (MWM) (in females) }\end{array}$ & $\begin{array}{l}\text { Zuena et } a .^{52}, \text { Laloux } \\
\text { et al. }{ }^{53}\end{array}$ \\
\hline Restraint ( 2.25 h/day) & $\begin{array}{l}\text { G14-G21 } \\
\text { G15-G20 }\end{array}$ & Sprague-Dawley rats & $\begin{array}{l}\downarrow \text { Time in the center (OF) (in males) } \\
\downarrow \text { Social interaction (in both sexes) } \\
\downarrow \text { Climbing and } \uparrow \text { Immobility time (FST) (in } \\
\text { males) } \\
=\text { No effects (SPT) }\end{array}$ & $\begin{array}{l}\text { Iturra-Mena et al. }{ }^{57} \\
\text { Poltyrev et al. }{ }^{58}\end{array}$ \\
\hline $\begin{array}{l}\text { Unpredictable } \\
\text { chronic stress } \\
\text { (1/day) }\end{array}$ & $\begin{array}{l}\text { G1-G7 } \\
\text { G8-G14 } \\
\text { G15-G21 }\end{array}$ & Wistar rats & $\begin{array}{l}=\text { or } \uparrow \text { Avoidance (ETM) } \\
\text { (depending on exposure period) }\end{array}$ & Soliani et al. ${ }^{56}$ \\
\hline $\begin{array}{l}\text { Unpredictable } \\
\text { chronic stress } \\
\text { (1/day) }\end{array}$ & G13-G21 & Wistar rats & $\begin{array}{l}\uparrow \text { Swim velocity (MWM) } \\
\uparrow \text { Object recognition (in females) }\end{array}$ & $\begin{array}{l}\text { Barbie-Shoshani } \\
\text { et al. }{ }^{59}\end{array}$ \\
\hline $\begin{array}{l}\text { Unpredictable } \\
\text { chronic stress } \\
\text { (80 foot shocks/day) }\end{array}$ & GO-PO & Wistar rats & $\downarrow$ Time and entries in open arms (EPM) & $\begin{array}{l}\text { Estanislau and } \\
\text { Morato }^{45}\end{array}$ \\
\hline $\begin{array}{l}\text { Maternal separation } \\
(1 \mathrm{~h} / \text { day })\end{array}$ & P1-P11 & C57BL/6 mice & $\downarrow$ Flexibility (4 choice-reversal learning) & Thomas et al. ${ }^{83}$ \\
\hline $\begin{array}{l}\text { Maternal and peer } \\
\text { separation } \\
\text { ( } 4 \text { h/day) }\end{array}$ & P2-P14 & C57BL/6 mice & $=$ No effects $(\mathrm{OF})$ & Bailoo et al. ${ }^{70}$ \\
\hline
\end{tabular}


Table 1 continued

\begin{tabular}{|c|c|c|c|c|}
\hline Stress type & Exposure period & Rodent model & Behavioral phenotypes & References \\
\hline Maternal separation & P2-P14 & C57BL/6 mice & $\begin{array}{l}\downarrow \text { Distance traveled and Rearings (in } \\
\text { males) (OF) }\end{array}$ & Bondar et al. ${ }^{65}$ \\
\hline \multirow[t]{2}{*}{ (4 h/day) } & & & $\downarrow$ Time in open arms (in females) (EPM) & \\
\hline & & & $\uparrow$ Social interactions (in females) & \\
\hline \multirow{2}{*}{$\begin{array}{l}\text { Maternal separation } \\
(3 \mathrm{~h} / \text { day) }\end{array}$} & P2-P14 & C57BL/6 mice & $\uparrow$ Time in the center and Rearings (OF) & Own and Patel ${ }^{69}$ \\
\hline & & & $\downarrow$ Latency to first immobility (FST) & \\
\hline \multirow{6}{*}{$\begin{array}{l}\text { Maternal separation } \\
\text { ( } 3 \mathrm{~h} \text { /day) }\end{array}$} & P2-P14 & $B A L B / C J R j$ & $\downarrow$ Exploration and time in the center (OF) & Teissier et al. ${ }^{67}$ \\
\hline & & & $\downarrow$ Time in open arms (EPM) & \\
\hline & & & $\uparrow$ Marble burying & \\
\hline & & & $\uparrow$ Immobility time (FST) & \\
\hline & & & $\downarrow$ Grooming time (Splash test) & \\
\hline & & & $\begin{array}{l}\downarrow \text { Short-term memory (Sequential novel } \\
\text { object recognition) }\end{array}$ & \\
\hline \multirow{4}{*}{$\begin{array}{l}\text { Maternal separation } \\
(4 \mathrm{~h} / \text { day })\end{array}$} & P2-P20 & C57BL/6 mice & $\uparrow$ Time and Entries in closed arms (EPM) & Shin et al..$^{79}$ \\
\hline & & & $=$ No effects (FST, Y-maze, MWM) & \\
\hline & & & $\uparrow$ Dominance (Tube test) & \\
\hline & & & $\begin{array}{l}\downarrow \text { Latency to first attack and } \uparrow \text { Number of } \\
\text { attacks (Resident intruder test) }\end{array}$ & \\
\hline \multirow[t]{2}{*}{$\begin{array}{l}\text { Maternal separation } \\
(1 \mathrm{~h} / \text { day })\end{array}$} & P3-P21 & C57BL/6 mice & $\begin{array}{l}\uparrow \text { Time in the center (OF) (after chronic social } \\
\text { defeat stress) }\end{array}$ & Qin et al. ${ }^{72}$ \\
\hline & & & $\begin{array}{l}\uparrow \text { Time and Entries in open arms (EPM) (after } \\
\text { chronic social defeat stress) }\end{array}$ & \\
\hline \multirow{3}{*}{$\begin{array}{l}\text { Maternal separation } \\
(4 \mathrm{~h} / \text { day })\end{array}$} & P10-P20 & C57BL/6J mice & $\downarrow$ Time in the center (OF) (after stress defeat) & Peña et al. ${ }^{64}$ \\
\hline & & & $\begin{array}{l}\uparrow \text { Immobility time (FST) and } \downarrow \text { Sucrose } \\
\text { consumption (SPT) (after stress defeat) }\end{array}$ & \\
\hline & & & $\downarrow$ Social interaction (after stress defeat) & \\
\hline Maternal separation & & C57BL/6J and DBA/2 mice & $\downarrow$ Time in the center (OF) & George et al. ${ }^{61}$ \\
\hline (4 h/day) & P2-P5 & & & \\
\hline (8 h/day) & P6-P16 & & & \\
\hline \multicolumn{5}{|l|}{ + early weaning (at P17) } \\
\hline & & & $\downarrow$ Entries in open arms (EPM) & \\
\hline & & & $\uparrow$ Immobility time (FST) (in DBA/2) & \\
\hline \multirow{4}{*}{$\begin{array}{l}\text { Maternal separation } \\
(6 \mathrm{~h} / \text { day) } \\
+ \text { early weaning (at P17) }\end{array}$} & P7-P15 & C57BL/6J mice & $\uparrow$ Immobility time (TST) & Tchenio et al. ${ }^{82}$ \\
\hline & & & & \\
\hline & & & $\downarrow$ Sucrose consumption (SPT) & \\
\hline & & & $\uparrow$ Failure to escapable shocks (Shuttle box) & \\
\hline Maternal separation & & Long Evans rats & $\downarrow$ Freezing to conspecific & Litvin et al. ${ }^{86}$ \\
\hline
\end{tabular}


Table 1 continued

\begin{tabular}{|c|c|c|c|c|}
\hline Stress type & Exposure period & Rodent model & Behavioral phenotypes & References \\
\hline (3 h/day) & P2-P13 & $\begin{array}{l}\downarrow \text { Unconditioned freezing } \\
\text { (cat odor) }\end{array}$ & & \\
\hline (6 h/day) & P11-P13 & & & \\
\hline $\begin{array}{l}\text { Maternal separation } \\
(3 \mathrm{~h} / \text { day })\end{array}$ & P1-P14 & Wistar rats & $=$ No effects (OF) & Farkas et al. ${ }^{68}$ \\
\hline Maternal separation & P2-P14 & Sprague-Dawley rats & $\downarrow$ Entries and Distance in the center (OF) & $\begin{array}{l}\text { Benekareddy } \\
\text { et al. }{ }^{62,63}\end{array}$ \\
\hline (3 h/day) & & & $\downarrow$ Entries and Distance in open arms (EPM) & \\
\hline $\begin{array}{l}\text { Maternal separation } \\
(3 \mathrm{~h} / \text { day })\end{array}$ & P2-P14 & Long Evans rats & $\begin{array}{l}\uparrow \text { Passive-submissive to proactive coping } \\
\text { (Social Defeat) }\end{array}$ & Gardner et al. ${ }^{85}$ \\
\hline $\begin{array}{l}\text { Maternal separation } \\
(3 \mathrm{~h} / \text { day })\end{array}$ & P2-P15 & Wistar rats & $\downarrow$ Time in open arms (EPM) & Uhelski and Fuchs ${ }^{76}$ \\
\hline \multirow{4}{*}{$\begin{array}{l}\text { Maternal separation } \\
(1,3 \mathrm{~h} / \text { day })\end{array}$} & P1-P14 & Wistar-Kyoto (WKY) & $\uparrow$ Exploration (in WKY) and $\downarrow$ (in $W$ ) (OF) & Rana et al. ${ }^{71}$ \\
\hline & & and Wistar $(\mathrm{W})$ rats & $\downarrow$ Grooming (in W) (OF) & \\
\hline & & & $\downarrow$ Immobility time (FST) (in WKY) & \\
\hline & & & $\uparrow$ Social interaction (in WKY) and $\downarrow$ (in $W$ ) & \\
\hline \multirow{2}{*}{$\begin{array}{l}\text { Maternal separation } \\
(6 \mathrm{~h} / \text { day })\end{array}$} & P2-P15 & Wistar rats & $\downarrow$ Time in the center (OF) & Roque et al..$^{77}$ \\
\hline & & & $\begin{array}{l}\downarrow \text { Latency to first immobility and } \uparrow \text { Immobility } \\
\text { time (FST) }\end{array}$ & \\
\hline \multirow{3}{*}{$\begin{array}{l}\text { Maternal and peer } \\
\text { separation } \\
\text { ( } 6 \text { h/day) }\end{array}$} & P4-P14 & Wistar rats & $\begin{array}{l}\downarrow \text { Latency to enter the dark and } \uparrow \text { Time in the } \\
\text { dark (Light-dark test) }\end{array}$ & Kambali et al. ${ }^{78}$ \\
\hline & & & $\begin{array}{l}\downarrow \text { Social novelty and } \uparrow \text { Spatial learning (Radial } \\
\text { arm maze) }\end{array}$ & \\
\hline & & & $\begin{array}{l}\uparrow \text { Attentional responses (5-Choice serial } \\
\text { reaction time) }\end{array}$ & \\
\hline \multirow[t]{2}{*}{$\begin{array}{l}\text { Maternal separation } \\
(4 \mathrm{~h} / \text { day })\end{array}$} & P2-P20 & Sprague-Dawley rats & $\begin{array}{l}\downarrow \text { Social interactions and } \uparrow \text { Latency to contact } \\
\text { (nose-to-nose) }\end{array}$ & Holland et al..$^{84}$ \\
\hline & & & $\downarrow$ Distance to conspecifics (in females) & \\
\hline \multirow{2}{*}{$\begin{array}{l}\text { Maternal separation } \\
(3 \mathrm{~h} / \text { day })\end{array}$} & P2-P21 & Sprague-Dawley rats & $\downarrow$ Distance in the center (OF) & Park et al. ${ }^{66}$ \\
\hline & & & $\begin{array}{l}\downarrow \text { Time and Entries in open arms (EPM) and } \uparrow \\
\text { Immobility time (FST) }\end{array}$ & \\
\hline \multirow[t]{2}{*}{$\begin{array}{l}\text { Limited bedding and } \\
\text { nesting material }\end{array}$} & P2-P9 & C57BL/6J mice & $\begin{array}{l}=\text { No effects (OF) and } \uparrow \text { Latency to } \\
\text { escape (MWM) }\end{array}$ & Rice et al. ${ }^{73}$ \\
\hline & & & $\downarrow$ Novel object exploration & \\
\hline \multirow[t]{2}{*}{$\begin{array}{l}\text { Limited bedding and } \\
\text { nesting material }\end{array}$} & P2-P9 & C57BL/6 mice & $\begin{array}{l}=\text { No effects (OF) and } \downarrow \text { Time and Entries in } \\
\text { bright compartment (Light-dark test) }\end{array}$ & Yang et al. ${ }^{74}$ \\
\hline & & & $\downarrow$ Activity (Y-maze) & \\
\hline $\begin{array}{l}\text { Limited bedding and } \\
\text { nesting material }\end{array}$ & P2-P9 & C57BL/6J mice & $\begin{array}{l}=\text { No effects (EPM, FST) and } \downarrow \text { Object } \\
\text { location memory }\end{array}$ & Naninck et al. ${ }^{81}$ \\
\hline
\end{tabular}


Table 1 continued

\begin{tabular}{|c|c|c|c|c|}
\hline Stress type & Exposure period & Rodent model & Behavioral phenotypes & References \\
\hline & & & $\downarrow$ Spatial learning (MWM) (in males) & \\
\hline \multirow{3}{*}{$\begin{array}{l}\text { Limited bedding and } \\
\text { nesting material }\end{array}$} & P4-P11 & C57BL/6 mice & $\uparrow$ Distance traveled (OF) (in kicked pups) & Gallo et al. ${ }^{75}$ \\
\hline & & & $\begin{array}{l}\text { Time in bright compartment ( } \uparrow \text { in kicked and } \\
\downarrow \text { in non-kicked pups) (Light-dark test) }\end{array}$ & \\
\hline & & & $=$ No effects (O-maze) & \\
\hline
\end{tabular}

In the studies where both sexes were analyzed, the sex-specific effects observed are indicated.

OF Open field, EPM Elevated plus maze, EZM Elevated Z-maze, MWM Morris water maze, NSF Novelty-suppressed feeding test, TST Tail suspension test, FST Forcedswim test, SPT Sucrose preference test, ETM Elevated T-maze.

phenotypes observed in these models, is the enhancement of anxiety behaviors, often accompanied by reduced locomotor and exploratory activities ${ }^{45-49}$. Additionally, these anxiety effects can predispose the offspring to other compulsive addictive behaviors like alcohol consump$\operatorname{tion}^{48}$ (Table 1). Importantly, stress exposure in the late phase of the pregnancy, somewhere within the period from gestational day $(\mathrm{G}) 11$ to postnatal day $(\mathrm{P}) 0$, in mice and rats, has also produced robust anxiety phenotypes ${ }^{50-}$ 57 (Table 1).

Depressive-like symptoms were also reported after gestational exposure to stress in rats ${ }^{49,58}$, though the evidence is more limited (Table 1).

Examination of other behavioral components associated with psychiatric conditions, such as the social interaction to conspecifics, showed a marked reduction after prenatal stress $^{57}$. In contrast, cognitive functions do not seem to be substantially affected in these models ${ }^{55}$, though moderate improvements in spatial learning ${ }^{52,59}$ and object recognition memory ${ }^{59}$, were observed in the offspring (Table 1).

\section{Postnatal stress: maternal separation, limited bedding and nesting material}

Other models directly expose the offspring to the stressful stimuli. The repeated maternal separation of the pups from the dams has been consistently used as an efficient stressful condition, especially when it happens during the lactation period ${ }^{60}$. This model sometimes also includes other stressors like the early weaning of the pups or a limited access to the bedding and nesting materials.

Protocols of maternal separation vary according to the time the pups spend isolated from their dams, but also to during which postnatal period the protocol is applied. Thus, while the time of separation typically ranges from 1 to $8 \mathrm{~h}$ per day, the postnatal period usually covers the first 2 or 3 postnatal weeks. In addition, in these models, distinctive behavioral effects can be observed when considering the mouse/rat strain and the sex of the offspring.
Daily separation from the dams during the first 2 or 3 postnatal weeks, in various mouse/rat strains, have consistently produced a reduction in the exploratory activity of the offspring ${ }^{61-67}$. Besides, these effects appeared to be more commonly detected in males than in female littermates ${ }^{65}$. However, other studies using slightly different conditions, could not reproduce these findings ${ }^{68-72}$. A combination of maternal separation with an early weaning of the pups also produced a decreased exploration ${ }^{61}$. On the other hand, stress protocols of limited access to bedding and nesting material, were shown to be inefficient per se to reproduce the exploratory defects ${ }^{73-75}$ (Table 1).

Anxiety phenotypes were consistently observed in various mouse/rat strains after maternal separation during the first $2^{62,63,65,67,71,76-78}$ or 3 postnatal weeks $\mathrm{s}^{61,64,66,79,80}$ (Table 1$)$. However, milder protocols $(1 \mathrm{~h} /$ day $)$ appeared to be insufficient to produce anxiety effects, after a chronic social distress ${ }^{72}$. On the other hand, anxiety phenotypes were reported to be more evident in females than in male descendants ${ }^{65}$. Lastly, less robust anxiety phenotypes were observed when both the dams and pups had a limited access to the bedding and nesting material during early postnatal life ${ }^{74,75,81}$ (Table 1 ).

Depressive-like behaviors have been repeatedly observed after maternal separation protocols in various mouse strains ${ }^{64,67,69}$, though others failed to reproduce these effects ${ }^{79}$. Similar depressive-like symptoms were reported when the maternal separation was followed by an early weaning in mice ${ }^{61,82}$. Interestingly, a mouse study suggested that the maternal separation from P10 to P20 would be sufficient to induce depressive-like symptoms in the offspring ${ }^{64}$. In rats, depressive-like phenotypes produced by maternal separation protocols are less robust. Thus, depressive-like symptoms were reported in Sprague-Dawley and Wistar rats ${ }^{66,77}$, while other studies using briefer protocols $(1.2 \mathrm{~h} /$ day $)$ in Wistar-Kyoto rats, have described the opposite effects ${ }^{71}$ (Table 1).

The impact of early maternal separation upon cognitive behaviors was consistently evidenced (Table 1). In 
general, postnatal exposures to stress appeared to have more profound consequences on cognitive abilities than prenatal exposures. Studies carried out in various mouse strains have shown deficits in behavioral flexibility ${ }^{83}$ and short-term memory ${ }^{67}$, after different maternal separation protocols. In contrast, no apparent effects were observed on spatial learning and working memory in mice ${ }^{79}$. However, in rats, improvements in spatial learning and attention were recently described ${ }^{78}$. Detrimental consequences of the limited bedding and nesting material have been observed on the novel object exploration and location memory ${ }^{73,81}$, accompanied by deficits in spatial learning and working memory tasks ${ }^{73,74,81}$ (Table 1).

Consequences of maternal separation on social behaviors were reported in mice and rats (Table 1). Thus, a delayed latency to initiate social contacts, and a decreased engagement in social interactions and activities, have been found ${ }^{64,71,78,84}$. However, other studies could not reproduce some of these effects ${ }^{65}$. Interestingly, distinct behavioral features associated with social behaviors, like aggression or dominance, were also found to be enhanced by maternal separation ${ }^{79,85}$. Consistent with this, a reduction of freezing responses to conspecifics, or after a punishment, were also observed ${ }^{86}$ (Table 1).

\section{Pharmacological models: behavioral outcomes}

Psychotropic drugs can interfere directly or indirectly with the brain's developmental trajectory. Importantly, the age period when such perturbations occur will define the emergence of long-lasting detrimental consequences on the individual's brain architecture and function. Rodent models have been very useful to understand how such dysregulation of neural mechanisms during developmental critical periods can impact adult behaviors. Here, we analyze the behavioral outcomes of two pharmacological models: the exposure to SSRI antidepressants, and to the anticonvulsant and mood stabilizer, VPA. Both drugs have a high capacity of crossing the placenta to reach the fetus ${ }^{10,87,88}$. While SSRIs inhibit the reuptake of 5-HT from the extracellular space by blocking the 5 -HT transporter, SERT, the precise mechanism of action of VPA is less known. In fact, it is thought that one of the main actions of VPA is to modulate the synthesis and metabolism of gammaaminobutyric acid (GABA), resulting in an enhancement of GABA neurotransmission ${ }^{87}$. Besides, VPA was also shown to have a direct inhibitory action on histone deacetylases (HDACs), modulating the epigenetic control of gene expression $^{89}$.

\section{Gestational exposure to SSRIs}

One of the most widely prescribed SSRI antidepressants is fluoxetine, and its exposure during the gestational period has a neurodevelopmental impact in the offspring
(Table 2), as indicated by a recent meta-analysis by Ramsteijn et al. ${ }^{90}$. Rat pups prenatally exposed to fluoxetine showed a mild delayed neurological maturation ${ }^{91}$, followed by a general reduction in exploratory behaviors, accompanied by anxiety and depressive-like phenotypes $^{92,93}$. On the other hand, studies applying a much broader schedule of fluoxetine treatment, covering from the last phase of the gestation to somewhere until the third postnatal week, could not detect such exploratory and emotional deficits ${ }^{94-98}$, while including the full gestational period produced emotional modifications ${ }^{99}$ (Table 2).

Regarding cognitive and social behaviors, only moderate effects of gestational exposures to SSRIs were observed (Table 2). Thus, no major changes in the exploration or memory of novel objects were detected in mice and rats $^{91,100}$. However, these studies did observe increments in conspecific exploration and aggression ${ }^{100}$. Consistently, an increased proportion of "attacker" individuals was found after fluoxetine exposure at later perinatal periods (G15 to P12) ${ }^{95,96}$. In the same conditions, no major effects on passive avoidance, fear conditioning, spatial learning and prepulse inhibition (PPI) were detected in mice ${ }^{94,96}$. On the other hand, in rats, the freezing behavior was shown to be enhanced by prenatal fluoxetine treatment, and several sex-specific social outcomes were also described $^{97,101,102}$ (Table 2).

\section{Postnatal exposure to SSRIs}

Other studies investigated the behavioral consequences of exposures to SSRIs during the early postnatal per$\operatorname{iod}^{10,12,103}$ (Table 2). Fluoxetine application during the first 2 or 3 postnatal weeks in various mouse/rat strains resulted in a marked reduction of exploratory behaviors, accompanied by the emergence of anxiety and depressivelike phenotypes ${ }^{103-112}$. Others, applying similar protocols of fluoxetine exposure, only partially reproduced these emotional effects ${ }^{113-116}$ (Table 2).

Other behavioral effects of relevance for psychiatric conditions were also reported after postnatal exposure to SSRIs. That is, several rat studies have reported reductions in ultrasonic vocalizations and sensorimotor responses, accompanied by alterations in social interactions to conspecifics ${ }^{104,105,115,117,118}$. On the other hand, spatial learning and memory abilities seemed not to be affected by the fluoxetine treatment at lower doses ${ }^{116,119}$ (Table 2), consistent with a recent meta-analysis ${ }^{90}$.

Postnatal exposure to other SSRIs like citalopram or escitalopram, during the same postnatal period, also produces anxiety and depressive-like phenotypes in mice ${ }^{120,121}$. However, other studies have only partially replicated some of these emotional effects ${ }^{122-125}$. In addition, citalopram exposure in the same period, was shown to reduce the exploration of novel objects and the 
Table 2 Rodent models of early-life exposure to SSRIs.

\begin{tabular}{|c|c|c|c|c|}
\hline SSRI (daily dose) & Exposure period & Rodent model & Behavioral phenotypes & References \\
\hline \multirow[t]{3}{*}{$\begin{array}{l}\text { Fluoxetine }(0.3-0.8 \mathrm{mg} / \mathrm{kg} \text { i. } \\
\text { p.) }\end{array}$} & \multirow[t]{3}{*}{ G8-G18 } & \multirow[t]{3}{*}{ C57BL/6J mice } & $\downarrow$ Distance traveled in the center (OF) & \multirow[t]{3}{*}{$\begin{array}{l}\text { Noorlander et al. }{ }^{92} \text {, Smit- } \\
\text { Rigter et al. }{ }^{93}\end{array}$} \\
\hline & & & $\uparrow$ Time in closed arms (EPM) & \\
\hline & & & $\uparrow$ Latency to feed (NSF) & \\
\hline \multirow[t]{5}{*}{ Fluoxetine (10 mg/kg s.c.) } & \multirow[t]{5}{*}{ G1-P0 } & \multirow[t]{5}{*}{ CD1 mice } & $\begin{array}{l}=\text { No effects (Novel object exploration, } \\
\text { Object memory test) }\end{array}$ & \multirow[t]{5}{*}{ Svirsky et al. ${ }^{100}$} \\
\hline & & & $\begin{array}{l}\uparrow \text { Animal exploration (Social preference } \\
\text { test) (only in young females) }\end{array}$ & \\
\hline & & & $=$ No effects (Social exploration and & \\
\hline & & & Social Memory tests) & \\
\hline & & & $\begin{array}{l}\uparrow \text { Number and Duration of attacks (Social } \\
\text { exploration and memory tests) }\end{array}$ & \\
\hline \multirow{7}{*}{$\begin{array}{l}\text { Fluoxetine }(25 \mathrm{mg} / \mathrm{kg} \\
\text { per os.) }\end{array}$} & \multirow[t]{7}{*}{ G15-P12 } & \multirow[t]{7}{*}{ C57BL/6 mice } & $=$ No effects (OF) & \multirow[t]{7}{*}{ Kiryanova et al. ${ }^{95,96}$} \\
\hline & & & $\begin{array}{l}\uparrow \text { Time in open arms and Number of } \\
\text { head dips (EPM) }\end{array}$ & \\
\hline & & & $\uparrow$ Spatial memory (MWM) & \\
\hline & & & $=$ No effects (Passive avoidance, PPI) & \\
\hline & & & $\uparrow$ Proportion of attackers & \\
\hline & & & $=$ No effects (Social interaction) & \\
\hline & & & (Resident intruder) & \\
\hline \multirow[t]{3}{*}{$\begin{array}{l}\text { Fluoxetine }(25 \mathrm{mg} / \mathrm{kg} \\
\text { per os.) }\end{array}$} & \multirow[t]{3}{*}{ G15-P12 } & \multirow[t]{3}{*}{ C57BL/6 mice } & $\begin{array}{l}=\text { No effects (OF, Horizontal ladder, PPI, } \\
\text { MWM, Fear conditioning) }\end{array}$ & \multirow[t]{3}{*}{ McAllister et al. ${ }^{94}$} \\
\hline & & & $\downarrow$ Time in closed arms (EPM) & \\
\hline & & & $\uparrow$ Latency to first immobility (FST) & \\
\hline \multirow[t]{3}{*}{$\begin{array}{l}\text { Fluoxetine }(10 \mathrm{mg} / \mathrm{kg} \\
\text { per os.) }\end{array}$} & \multirow[t]{3}{*}{ G0-P14 } & \multirow[t]{3}{*}{$\begin{array}{l}\text { Sprague-Dawley and } \\
\text { Wistar-Kyoto rats }\end{array}$} & $\downarrow$ Time in the center (OF) & \multirow[t]{3}{*}{ Millard et al..$^{99}$} \\
\hline & & & $\downarrow$ Time in open arms (EPM) & \\
\hline & & & $\uparrow$ Immobility time (FST) & \\
\hline $\begin{array}{l}\text { Fluoxetine }(10 \mathrm{mg} / \mathrm{kg} \text { per } \\
\text { gavage) }\end{array}$ & G0-P21 & Wistar rats & $\begin{array}{l}\downarrow \text { Third-party prosocial behavior (in } \\
\text { females) }\end{array}$ & Heinla et al. ${ }^{102}$ \\
\hline $\begin{array}{l}\text { Fluoxetine }(5 \mathrm{mg} / \mathrm{kg} \text { per } \\
\text { gavage) }\end{array}$ & G1-P21 & Wistar rats & $=$ No effects (OF, EPM) & Toffoli et al. ${ }^{98}$ \\
\hline \multirow{8}{*}{$\begin{array}{l}\text { Fluoxetine (10 mg/kg } \\
\text { per os.) }\end{array}$} & \multirow[t]{8}{*}{ G10-P21 } & \multirow[t]{8}{*}{ Sprague-Dawley rats } & In females: & \multirow[t]{8}{*}{ Gemmel et al. ${ }^{101}$} \\
\hline & & & $\uparrow$ Time interacting with another female & \\
\hline & & & $\uparrow$ Time in social investigation & \\
\hline & & & $\downarrow$ Time to first interaction & \\
\hline & & & In males: & \\
\hline & & & $\uparrow$ Time in social play & \\
\hline & & & $\uparrow$ Running away from a novel partner & \\
\hline & & & $\uparrow$ Self grooming & \\
\hline
\end{tabular}


Table 2 continued

\begin{tabular}{|c|c|c|c|c|}
\hline SSRI (daily dose) & Exposure period & Rodent model & Behavioral phenotypes & References \\
\hline \multirow{6}{*}{$\begin{array}{l}\text { Fluoxetine ( } 12 \mathrm{mg} / \mathrm{kg} \text { per } \\
\text { gavage) }\end{array}$} & G11-P0 & Wistar rats & $=$ No effects (OF, EPM, SPT, FST) & Olivier et al. ${ }^{97}$ \\
\hline & & & $\uparrow$ Latency to feed (NSF) & \\
\hline & & & $\begin{array}{l}\uparrow \text { Freezing and } \downarrow \text { Time in the shock } \\
\text { compartment }\end{array}$ & \\
\hline & & & (Place aversion) & \\
\hline & & & $\downarrow$ Juvenile social play and exploration & \\
\hline & & & $\begin{array}{l}\downarrow \text { Adult self-grooming and social } \\
\text { exploration }\end{array}$ & \\
\hline \multirow{6}{*}{$\begin{array}{l}\text { Fluoxetine ( } 12 \mathrm{mg} / \mathrm{kg} \text { per } \\
\text { gavage) }\end{array}$} & G11-P7 & Wistar rats & $\uparrow$ Turning time (Negative geotaxis) & Kroeze et al. ${ }^{91}$ \\
\hline & & & $\uparrow$ Age (Vibrissa placement) & \\
\hline & & & $\uparrow$ Age (Startle reflex) & \\
\hline & & & $\begin{array}{l}\downarrow \text { Locomotor and motor abilities (at early } \\
\text { postnatal ages) }\end{array}$ & \\
\hline & & & $\downarrow$ Grooming & \\
\hline & & & $\begin{array}{l}=\text { No effects (NOR, Object directed } \\
\text { behavior) }\end{array}$ & \\
\hline \multirow[t]{4}{*}{ Fluoxetine (10 mg/kg i.p.) } & P4-P21 & 129S6/SvEvTac mice & $\begin{array}{l}\downarrow \text { Distance traveled, Rearing and } \\
\text { Ambulation times (OF) }\end{array}$ & Ansorge et al. ${ }^{103}$ \\
\hline & & & $\downarrow$ Number of open arm entries (EPM) & \\
\hline & & & $\begin{array}{l}\uparrow \text { Latency to escape (shock-avoidance/ } \\
\text { escape) }\end{array}$ & \\
\hline & & & $\uparrow$ Latency to feed (NSF) & \\
\hline \multirow[t]{2}{*}{ Fluoxetine (10 mg/kg i.p.) } & P2-P11 & 129S6/SvEvTac mice & $\downarrow$ Sucrose consumption (SPT) & $\begin{array}{l}\text { Rebello et al. }{ }^{106} \text {, Teissier } \\
\text { et al. }{ }^{107}\end{array}$ \\
\hline & & & $\uparrow$ Immobility time (FST) & \\
\hline \multirow{2}{*}{$\begin{array}{l}\text { Fluoxetine }(10 \mathrm{mg} / \mathrm{kg} \\
\text { per os.) }\end{array}$} & P2-P14 & C57BL/6J mice & $\uparrow$ Latency to feed (NSF) & Soiza-Reilly et al. ${ }^{111}$ \\
\hline & & & $\uparrow$ Immobility time (FST) & \\
\hline \multirow[t]{4}{*}{ Fluoxetine (10 mg/kg s.c.) } & P2-P14 & C57BL/6J mice & $\begin{array}{l}\downarrow \text { Time and Total distance in the } \\
\text { center (OF) }\end{array}$ & Olusakin et al..$^{112}$ \\
\hline & & & $\uparrow$ Latency to feed (NSF) & \\
\hline & & & $\uparrow$ Immobility time (FST) & \\
\hline & & & $\uparrow$ Latency to groom (Splash test) & \\
\hline Fluoxetine (5 mg/kg per os.) & P1-P21 & C57BL/6J mice & $=$ No effects (MWM) & Ishiwata et al. ${ }^{119}$ \\
\hline \multirow[t]{3}{*}{ Fluoxetine (10 mg/kg i.p.) } & P4-P21 & C57BL/6J mice & $\begin{array}{l}\uparrow \text { Immobility time in the center, } \downarrow \text { Total } \\
\text { rearing time (OF) }\end{array}$ & Karpova et al. ${ }^{113}$ \\
\hline & & & $\uparrow$ Total immobility time (Light-Dark) & \\
\hline & & & $\downarrow$ Immobility time (FST) & \\
\hline \multirow[t]{2}{*}{ Fluoxetine ( $5 \mathrm{mg} / \mathrm{kg}$ per os.) } & P1-P21 & $\mathrm{BALB} / \mathrm{c}$ mice & $\uparrow$ Time and Entries in open arms (EPM) & Ishikawa and Shiga ${ }^{116}$ \\
\hline & & & $=$ No effects (FST, SPT, MWM) & \\
\hline
\end{tabular}


Table 2 continued

\begin{tabular}{|c|c|c|c|c|}
\hline SSRI (daily dose) & Exposure period & Rodent model & Behavioral phenotypes & References \\
\hline \multirow[t]{3}{*}{ Fluoxetine (10 mg/kg s.c.) } & P0-P6 & Wistar rats & $\downarrow$ Maximum crossable gap distance & Lee et al. $^{117}$ \\
\hline & & & (Gap-crossing) & \\
\hline & & & $\begin{array}{l}\downarrow \text { Ambulation in the center and } \\
\text { rearing (OF) }\end{array}$ & \\
\hline \multirow[t]{5}{*}{ Fluoxetine (20 mg/kg s.c.) } & P0-P4 & Wistar rats & $\begin{array}{l}\downarrow \text { Distance traveled and ambulation in } \\
\text { the center (OF) }\end{array}$ & Ko et al. ${ }^{115}$ \\
\hline & & & $\begin{array}{l}\downarrow \text { Number of closed arm entries and of } \\
\text { total distance traveled (EPM) }\end{array}$ & \\
\hline & & & $\uparrow$ Time spent in immobility (FST) & \\
\hline & & & $\downarrow$ Sensorimotor gating (PPI) & \\
\hline & & & $\uparrow$ Social interaction, sniffing and contacts & \\
\hline \multirow[t]{2}{*}{$\begin{array}{l}\text { Fluoxetine }(10 \mathrm{mg} / \mathrm{kg} \text { per } \\
\text { gavage) }\end{array}$} & P2-P7 & $\mathrm{NIH}$ Norway rats & $\downarrow$ Ultrasonic vocalizations (PPI) & $\begin{array}{l}\text { Zimmerberg and } \\
\text { Germeyan }^{118}\end{array}$ \\
\hline & & & $\downarrow$ Interaction time with conspecific & \\
\hline \multirow{7}{*}{$\begin{array}{l}\text { Fluoxetine (5 mg/kg s.c. } \\
\text { osmotic minipump in dams) }\end{array}$} & P1-P21 & Sprague-Dawley rats & In females: & Boulle et al. ${ }^{109,110}$ \\
\hline & & & $=$ No effects (OF, EZM) & \\
\hline & & & $\uparrow$ Immobility time (FST) & \\
\hline & & & In males: & \\
\hline & & & $\downarrow$ Center entries (OF) & \\
\hline & & & $\downarrow$ Distance traveled (EZM) & \\
\hline & & & $=$ No effects $($ FST) & \\
\hline \multirow[t]{2}{*}{ Fluoxetine (10 mg/kg s.c.) } & $P 1-P 21$ & Wistar rats & $\downarrow$ Time in closed arms & Da Silva et al. ${ }^{114}$ \\
\hline & & & $\begin{array}{l}\uparrow \text { Number of open arm entries and Time } \\
\text { in open arms (EPM) }\end{array}$ & \\
\hline \multirow[t]{4}{*}{$\begin{array}{l}\text { Fluoxetine }(10 \mathrm{mg} / \mathrm{kg} \\
\text { per os.) }\end{array}$} & P2-P21 & Sprague-Dawley rats & $\begin{array}{l}\downarrow \text { Time and Traveled distance in the } \\
\text { center (OF) }\end{array}$ & Sarkar et al. ${ }^{104,105}$ \\
\hline & & & $\begin{array}{l}\downarrow \text { Path length and time in open } \\
\text { arms (EPM) }\end{array}$ & \\
\hline & & & $\uparrow$ Immobility time (FST) & \\
\hline & & & $\begin{array}{l}\downarrow \text { Juvenile play behavior and Time in } \\
\text { social grooming }\end{array}$ & \\
\hline \multirow{3}{*}{$\begin{array}{l}\text { Fluoxetine }(10 \mathrm{mg} / \mathrm{kg} \text { i.p. } \\
\text { in dams) }\end{array}$} & P2-P24 & Sprague-Dawley rats & $\uparrow$ Time in closed arms (EPM) (in males) & Gobinath et al. ${ }^{108}$ \\
\hline & & & $\uparrow$ Latency to feed (NSF) (in males) & \\
\hline & & & $\uparrow$ Swim time (FST) & \\
\hline \multirow[t]{4}{*}{ Citalopram (10 mg/kg i.p.) } & P4-P21 & 129S6/SvEv mice & $\downarrow$ Total ambulatory time (OF) & Ansorge et al. ${ }^{121}$ \\
\hline & & & $\downarrow$ Total number of arm entries (EPM) & \\
\hline & & & $\uparrow$ Latency to escape (shock-escape) & \\
\hline & & & $\begin{array}{l}\uparrow \text { Latency to drink (novelty-induced } \\
\text { hypophagia) }\end{array}$ & \\
\hline Citalopram (20 mg/kg s.c.) & P1-P10 & Sprague-Dawley rats & & Zhou et al. ${ }^{214}$ \\
\hline
\end{tabular}


Table 2 continued

\begin{tabular}{|c|c|c|c|c|}
\hline SSRI (daily dose) & Exposure period & Rodent model & Behavioral phenotypes & References \\
\hline & & & $\begin{array}{l}\uparrow \text { Auditory discrimination threshold (in } \\
\text { males) }\end{array}$ & \\
\hline \multirow[t]{2}{*}{ Citalopram (10 mg/kg s.c.) } & P8-P21 & Long Evans rats & $\begin{array}{l}\uparrow \text { Distance traveled and ambulatory } \\
\text { time (OF) }\end{array}$ & $\begin{array}{l}\text { Maciag et al. }{ }^{122,123} \text {, Harris } \\
\text { et al. }{ }^{124}\end{array}$ \\
\hline & & & $\begin{array}{l}=\text { No effects (EPM, FST, Saccharine- } \\
\text { sweetened fluid consumption) }\end{array}$ & \\
\hline \multirow[t]{3}{*}{ Citalopram (20 mg/kg s.c.) } & P8-P21 & Long Evans rats & $\begin{array}{l}\uparrow \text { Stereotypic behaviors and Freezing } \\
\text { after tone (stronger in males) }\end{array}$ & $\begin{array}{l}\text { Simpson et al. [126], } \\
\text { Rodriguez-Porcel et al. }{ }^{127} \\
\text { Khatri et al. }{ }^{128}\end{array}$ \\
\hline & & & $\begin{array}{l}\downarrow \text { Exploration of novel object (stronger in } \\
\text { males) }\end{array}$ & \\
\hline & & & $\begin{array}{l}\downarrow \text { Juvenile play behavior and interaction } \\
\text { to conspecifics (stronger in males) }\end{array}$ & \\
\hline \multirow[t]{5}{*}{ Escitalopram (10 mg/kg s.c.) } & P5-P19 & CD1 mice & $\downarrow$ Total arm entries and rears (EPM) & Popa et al. ${ }^{120}$ \\
\hline & & & $\downarrow$ Sucrose consumption and intake (SPT) & \\
\hline & & & $\uparrow$ Immobility time (FST and TST) & \\
\hline & & & $\uparrow$ REM sleep (pro-depressive) & \\
\hline & & & $=$ No effects (light-dark) & \\
\hline \multirow[t]{2}{*}{ Escitalopram (10 mg/kg s.c.) } & P5-P21 & CD1 1 129SvEv mice & $\uparrow$ Time and Entries in Open arms (EPM) & Altieri et al. ${ }^{125}$ \\
\hline & & & $=$ No effects (OF, FST) & \\
\hline
\end{tabular}

In the studies where both sexes were analyzed, the sex-specific effects observed are indicated.

OF Open field, EPM Elevated plus maze, PPI Prepulse inhibition, MWM Morris water maze, NSF Novelty-suppressed feeding test, TST Tail suspension test, FST Forcedswim test, SPT Sucrose preference test, EZM Elevated Z-maze.

engagement in juvenile play, besides of exacerbating the freezing response to a tone ${ }^{126-128}$ (Table 2).

Since SSRIs are often prescribed to depressed pregnant women, preclinical investigations on the possible interaction of these treatments with the maternal stress become highly relevant for obvious direct translational reasons. Several studies have shown that early postnatal fluoxetine treatment in pups exposed to either prenatal stress or maternal separation, can alleviate anxiety and depressive-like symptoms produced in these models $^{110,129-131}$. However, this does not seem to be the case when using another SSRI (i.e., citalopram) ${ }^{132}$.

\section{Gestational and postnatal exposures to VPA}

Acute treatment with a high dose of VPA during pregnancy causes a wide repertoire of emotional, social and cognitive alterations in the offspring (Table 3). Although the exact molecular mechanism of action of this drug remains unknown, VPA has been consistently applied during neurodevelopment in an attempt to replicate common phenotypic features present in ASD patients $^{39,40}$.
Most of the studies reporting behavioral effects in various mouse/rat strains use a single dose of VPA $(400-800 \mathrm{mg} / \mathrm{kg})$ in a given day, within the period G11-G13 (Table 3). In these conditions, the exposedoffspring presents substantial neurological maturation delays $^{133-135}$, usually accompanied by a reduced exploratory activity ${ }^{136-138}$, and the enhancement of selfgrooming and stereotypic behaviors ${ }^{133-136,138-148}$. This is highly consistent with the exacerbation of repetitive behaviors observed in ASD patients ${ }^{39,40}$. Interestingly, long-lasting deficits in motor and procedural skills were also observed after VPA exposure ${ }^{144}$. On the contrary, neither lower doses nor VPA exposures before or after such gestational period, lead to robust behavioral outcomes $^{133,136,137,141,149-151}$ (Table 3).

Anxiety phenotypes induced by VPA exposure during the pregnancy were more consistently found in rats than in mice ${ }^{135,137-139,142,146,147,152-157}$. However, other studies could not replicate some of these effects ${ }^{144}$. On the other hand, the emergence of depressive-like symptoms was also reported in a mouse study ${ }^{147}$ (Table 3). 
Table 3 Rodent models of VPA exposure.

\begin{tabular}{|c|c|c|c|c|}
\hline VPA dose & Exposure period & Rodent model & Behavioral phenotypes & References \\
\hline \multirow[t]{5}{*}{500 mg/kg i.p. } & G9, G12.5, or G14.5 & ICR(CD1) mice & $\begin{array}{l}\downarrow \text { Distance and Entries in the center (OF) (for } \\
\text { G12.5, in both sexes) }\end{array}$ & Kataoka et al. ${ }^{137}$ \\
\hline & & & $\begin{array}{l}\downarrow \text { Time in open arms (EPM) (for G12.5, in both } \\
\text { sexes) }\end{array}$ & \\
\hline & & & $\begin{array}{l}\downarrow \text { Social interaction (Sniffing) (for G12.5, } \\
\text { in males) }\end{array}$ & \\
\hline & & & $\begin{array}{l}\uparrow \text { Social interaction (Sniffing) (for G12.5, in } \\
\text { females) }\end{array}$ & \\
\hline & & & $\downarrow$ Spatial learning (MWM) (for G12.5) & \\
\hline \multirow[t]{3}{*}{$800 \mathrm{mg} / \mathrm{kg}$ per os. } & G11 & $\begin{array}{l}\text { Hybrid mice (C57BL/6, CF- } \\
\text { 1, Swiss, DBA/2) }\end{array}$ & $\uparrow$ Latency to reach home bedding & Roullet et al. ${ }^{158}$ \\
\hline & & & $\downarrow$ Social behavior (Nose pokes) & \\
\hline & & & $\downarrow$ Social novelty (Nose pokes) & \\
\hline \multirow[t]{2}{*}{$200 \mathrm{mg} / \mathrm{kg}$ s.c. } & G12-G17 & $\mathrm{BALB} / \mathrm{c}$ mice & $\begin{array}{l}=\text { No major effects (Negative geotaxis, Surface } \\
\text { righting, Balance beam). }\end{array}$ & Wagner et al. ${ }^{133}$ \\
\hline & & & $\begin{array}{l}\uparrow \text { Delay (Surface and Mid-air righting) (in both } \\
\text { sexes) }\end{array}$ & \\
\hline \multirow[t]{3}{*}{600 mg/kg s.c. } & G13 & & $\downarrow$ Latency to fall (Grip strength) (in both sexes) & \\
\hline & & & $\uparrow$ Locomotor activity & \\
\hline & & & $\downarrow$ Spatial learning (MWM) (in both sexes) & \\
\hline \multirow[t]{7}{*}{$600 \mathrm{mg} / \mathrm{kg}$ s.c. } & G12.5 & Crl:Fcen:CF1 mice & $\downarrow$ Juvenile play (Solicitations, sniffing, Following) & $\begin{array}{l}\text { Campolongo et al. }{ }^{147} \text {, } \\
\text { Acosta et al. }{ }^{167} \text {, Kazlaukas } \\
\text { et al. }{ }^{162}\end{array}$ \\
\hline & & & $\uparrow$ Self-grooming & \\
\hline & & & $\downarrow$ Alternation and distance (Y-maze, EPM, OF) & \\
\hline & & & $\begin{array}{l}=\text { No effects (Affiliative and Non-social } \\
\text { behaviors, Odor habituation, NOR, Light- } \\
\text { dark test) }\end{array}$ & \\
\hline & & & $\begin{array}{l}\downarrow \text { Social preference and interaction (Sniffing) (in } \\
\text { males) }\end{array}$ & \\
\hline & & & $\uparrow$ Immobility time (TST, FST) & \\
\hline & & & $\begin{array}{l}\downarrow \text { Temporal Accuracy and Precision (Interval } \\
\text { timing) }\end{array}$ & \\
\hline \multirow[t]{4}{*}{500 mg/kg i.p. } & G12.5 & C57BL/6J mice & $\uparrow$ Marble burying & Wu et al. ${ }^{164}$ \\
\hline & & & $\downarrow$ Social interaction (time) & \\
\hline & & & $\downarrow$ Social preference (time) & \\
\hline & & & $\downarrow$ Learning (Negative Reinforcement Task) & \\
\hline \multirow[t]{3}{*}{600 mg/kg i.p. } & G12.5 & C57BL/6J mice & $\uparrow$ Grooming and Digging time & Moldrich et al. ${ }^{145}$ \\
\hline & & & $\begin{array}{l}\downarrow \text { Social interaction (time, nose pokes, } \\
\text { approaches) }\end{array}$ & \\
\hline & & & $\downarrow$ Olfactory motivation & \\
\hline \multirow[t]{2}{*}{$600 \mathrm{mg} / \mathrm{kg}$ s.c. } & G13 & C57BL/6Hsd mice & $\downarrow$ Entries and Time in the center (OF) & Mehta et al. ${ }^{138}$ \\
\hline & & & $\uparrow$ Self-grooming and Marble burying & \\
\hline \multirow[t]{3}{*}{800 mg/kg per os. } & G9 & Wistar rats & $\begin{array}{l}\downarrow \text { Time of all pellet consumption and } \\
\text { Exploration (Radial maze) }\end{array}$ & Narita et al. ${ }^{136}$ \\
\hline & & & $\begin{array}{l}\uparrow \text { Locomotor activity without anxiety } \\
\text { effects (OF) }\end{array}$ & \\
\hline & & & $=$ No effects (Social interaction) & \\
\hline 600 mg/kg i.p. & G9 & Wistar rats & $\begin{array}{l}\uparrow \text { Time spent in empty compartment, } \uparrow \\
\text { Crossings between social compartments, } \downarrow \\
\text { Initiation of social approaches }\end{array}$ & Dufour-Rainfray et al. ${ }^{149}$ \\
\hline \multirow[t]{2}{*}{$800 \mathrm{mg} / \mathrm{kg}$ per gavage } & G9 & Wistar rats & $\uparrow$ Locomotor activity (OF) (in light/sleep phase) & Tsujino et al. ${ }^{141}$ \\
\hline & & & $\uparrow$ Feeding (in light/sleep phase) & \\
\hline \multirow[t]{3}{*}{500 mg/kg i.p. } & G11.5 & Wistar Han rats & $\uparrow$ Entries to the same arm (Y-maze) & Favre et al. ${ }^{160}$ \\
\hline & & & $\downarrow$ Social preference (sniffing) & \\
\hline & & & $\uparrow$ Freezing (Pavlovian fear conditioning) & \\
\hline \multirow[t]{2}{*}{600 mg/kg i.p. } & G12.5 & Wistar rats & $\begin{array}{l}\uparrow \text { Latency to reach home bedding (olfactory } \\
\text { discrimination in pups) }\end{array}$ & $\begin{array}{l}\text { Schneider and Przewłocki }{ }^{134}, \\
\text { Schneider et al. } .^{139,140,152}\end{array}$ \\
\hline & & & $\downarrow$ Angle of swim (in pups) & \\
\hline
\end{tabular}


Table 3 continued

\begin{tabular}{|c|c|c|c|c|}
\hline VPA dose & Exposure period & Rodent model & Behavioral phenotypes & References \\
\hline & & & $\begin{array}{l}\uparrow \text { Locomotor and Stereotypic behavior (in both } \\
\text { sexes) }\end{array}$ & \\
\hline & & & $\downarrow$ Exploratory activity (Rearing and hole poking) & \\
\hline & & & $\downarrow$ Entries and Time in open arms (EPM) (in males) & \\
\hline & & & $\downarrow$ Sensorimotor gating (PPI) & \\
\hline & & & $\begin{array}{l}\downarrow \text { Social play and Social exploration behavior (in } \\
\text { males) }\end{array}$ & \\
\hline & & & $=$ No effects (NOR) & \\
\hline \multirow[t]{6}{*}{500 mg/kg i.p. } & G12.5 & Wistar Han rats & $\uparrow$ Entries to the same arm (Y-maze) & Markram et al. ${ }^{142}$ \\
\hline & & & $\downarrow$ Time in open arms (EPM) & \\
\hline & & & $\downarrow$ Social interaction (sniffing, touching) & \\
\hline & & & $\downarrow$ Sensorimotor gating (PPI) & \\
\hline & & & $\begin{array}{l}\uparrow \text { Tone and Context memories, Generalization } \\
\text { and Extinction (Fear conditioning) }\end{array}$ & \\
\hline & & & $=$ No effects (Locomotion, MWM) & \\
\hline \multirow[t]{4}{*}{$500 \mathrm{mg} / \mathrm{kg}$ i.p. } & G12.5 & Wistar rats & $\uparrow$ Time in closed arms (EPM) (in both sexes) & Edalatmanesh et al..$^{146}$ \\
\hline & & & $\begin{array}{l}\uparrow \text { Repetitive behavior and } \downarrow \text { Alternation } \\
\text { behavior (Y-maze) (in both sexes) }\end{array}$ & \\
\hline & & & $\begin{array}{l}\downarrow \text { Play behavior, Social exploration and contact } \\
\text { (in both sexes) }\end{array}$ & \\
\hline & & & $\begin{array}{l}\uparrow \text { Spatial learning and memory (MWM) (in both } \\
\text { sexes) }\end{array}$ & \\
\hline \multirow[t]{4}{*}{$400 \mathrm{mg} / \mathrm{kg}$ s.c. } & G12.5 & Wistar rats & $\downarrow$ Time in open arms (EPM) & Ellenbroek et al. ${ }^{155}$ \\
\hline & & & $\uparrow$ Latency to feed (NSF) & \\
\hline & & & $\uparrow$ Sucrose consumption (Latent inhibition) & \\
\hline & & & $\downarrow$ Sensorimotor gating (PPI) & \\
\hline \multirow[t]{3}{*}{600 mg/kg i.p. } & G12.5 & Wistar rats & $\downarrow$ Social exploration and preference & Bambini-Junior et al. ${ }^{143}$ \\
\hline & & & $\uparrow$ Alternation delay (Y-maze) & \\
\hline & & & $=$ No effects (MWM) & \\
\hline 600 mg/kg i.p. & G12.5 & Wistar rats & $\downarrow$ Time in the center (OF) (in both sexes) & Olexová et al. ${ }^{156}$ \\
\hline \multirow[t]{2}{*}{$400 \mathrm{mg} / \mathrm{kg}$ s.c. } & $\mathrm{G} 7, \mathrm{G} 9.5, \mathrm{G} 12$ or G15 & Sprague-Dawley rats & $\begin{array}{l}\downarrow \text { Interaction to familiar and novel conspecifics } \\
\text { (more robust for G12 exposure, in males) }\end{array}$ & Kim et al. ${ }^{150,159}$ \\
\hline & & & $\downarrow$ Social preference (in males) & \\
\hline \multirow[t]{6}{*}{$500 \mathrm{mg} / \mathrm{kg}$ per gavage } & G11-13 & Sprague-Dawley rats & $\downarrow$ Ultrasonic vocalizations (in both sexes) & Barrett et al. ${ }^{157}$ \\
\hline & & & $\downarrow$ Time in the center (OF) (in females) & \\
\hline & & & $\uparrow$ Baseline startle amplitude (in males) & \\
\hline & & & $\begin{array}{l}\uparrow \text { Startle response (after Fear conditioning) (in } \\
\text { both sexes) }\end{array}$ & \\
\hline & & & $\downarrow$ Approach to a social stimulus (in both sexes) & \\
\hline & & & $\downarrow$ Novel social interaction (in males) & \\
\hline 600 mg/kg i.p. & G12 & Sprague-Dawley rats & $\uparrow$ Freezing (Trace and Delay Fear conditioning) & Sui and Chen ${ }^{165}$ \\
\hline \multirow{4}{*}{500 mg/kg i.p. } & G12.5 & Sprague-Dawley rats & $\downarrow$ Time in the center (OF) & Lin et al. ${ }^{153}$ \\
\hline & & & $\downarrow$ Time in open arms (EPM) & \\
\hline & & & $\downarrow$ Social interaction (duration and frequency) & \\
\hline & & & $\uparrow$ Freezing (Contextual fear conditioning) & \\
\hline 500 mg/kg i.p. & G12.5 & Sprague-Dawley rats & $\downarrow$ Ultrasonic vocalizations (in both sexes) & Gzielo et al. ${ }^{163}$ \\
\hline \multirow[t]{8}{*}{600 mg/kg i.p. } & G12.5 & Sprague-Dawley rats & $\begin{array}{l}\uparrow \text { Delays in Surface and Air righting reflexes, } \\
\text { Negative geotaxis, Cliff aversion, Crawling and } \\
\text { Visual placing reflex }\end{array}$ & Hou et al. ${ }^{135}$ \\
\hline & & & $\begin{array}{l}\downarrow \text { Motor abilities (Swimming, Front limb } \\
\text { suspension) }\end{array}$ & \\
\hline & & & $\uparrow$ Onset of auditory startle & \\
\hline & & & $\uparrow$ Self-grooming & \\
\hline & & & $\downarrow$ Center entries (OF) & \\
\hline & & & $\downarrow$ Social preference and interaction & \\
\hline & & & $\downarrow$ Novel social interaction & \\
\hline & & & $\downarrow$ Spatial learning (MWM) & \\
\hline
\end{tabular}


Table 3 continued

\begin{tabular}{|c|c|c|c|c|}
\hline VPA dose & Exposure period & Rodent model & Behavioral phenotypes & References \\
\hline $500-600$ mg/kg i.p. & G12.5 & Sprague-Dawley rats & $\begin{array}{l}\uparrow \text { Freezing (Fear conditioning) } \\
\downarrow \text { Entries and Distance traveled in the } \\
\text { center (OF) } \\
\downarrow \text { Social interaction and Social visits } \\
=\text { No effects (NOR) }\end{array}$ & $\begin{array}{l}\text { Wang et al. }{ }^{166} \text {, Banerjee } \\
\text { et al. }\end{array}$ \\
\hline 800 mg/kg per os. & G12 & Long Evans rats & $\begin{array}{l}\downarrow \text { Performance (T-maze) (in both sexes) } \\
\uparrow \text { Time in open arms (EPM) (in both sexes) } \\
\uparrow \text { Interaction to familiar object (NOR) (in both } \\
\text { sexes) } \\
\uparrow \text { Performance (Whishaw tray reaching test) (in } \\
\text { males) } \\
\downarrow \text { Performance (Whishaw tray reaching test) (in } \\
\text { females) }\end{array}$ & Mychasiuk et al. ${ }^{144}$ \\
\hline 600 mg/kg i.p. & G12 & Long Evans rats & $\begin{array}{l}\downarrow \text { Sniffing (in females) } \\
\uparrow \text { Self-grooming (in both sexes) } \\
\uparrow \text { Interaction to familiar object (NOR) (in males) } \\
\downarrow \text { Marble burying } \\
\downarrow \text { Performance (Set shifting task) (in both sexes, } \\
\text { stronger effects in females) }\end{array}$ & McKinnell et al. ${ }^{148}$ \\
\hline 800 mg/kg per os. & G12.5 & Long Evans rats (females) & $\begin{array}{l}\downarrow \text { Defensive rotation tactic and } \uparrow \text { Standing tactic } \\
\uparrow \text { Frequency of Mounting, Head and Body } \\
\text { shaking } \\
\downarrow \text { Ultrasonic vocalizations (at Social play) } \\
=\text { No effects (Playful attacks) }\end{array}$ & Raza et al. ${ }^{161}$ \\
\hline 350 mg/kg i.p. & G13 & Long Evans rats & $\begin{array}{l}\uparrow \text { Social exploration and Play fighting (in } \\
\text { adolescence) }\end{array}$ & Cohen et al. ${ }^{151}$ \\
\hline $200-400 \mathrm{mg} / \mathrm{kg}$ s.c. & P14 & $\mathrm{BALB} / \mathrm{c}$ mice & $\begin{array}{l}=\text { No effects (Grip strength, Balance beam, } \\
\text { Locomotor activity) and } \uparrow \text { Delay in Negative } \\
\text { geotaxis and Mid-air righting } \\
\downarrow \text { Spatial learning (MWM) and } \uparrow \text { Latency (Passive } \\
\text { avoidance) }\end{array}$ & Wagner et al. ${ }^{133}$ \\
\hline 400 mg/kg s.c. & P14 & BALB/c mice & $\begin{array}{l}\downarrow \text { Social behaviors (allogrooming, crawl under/ } \\
\text { over, sniffing) } \\
\downarrow \text { Motor activity (in social environment) } \\
\uparrow \text { Locomotor activity }\end{array}$ & Yochum et al. ${ }^{170}$ \\
\hline 400 mg/kg s.c. & P14 & C57BL/6J mice & $\begin{array}{l}\uparrow \text { Time in open arms (EPM) (only in males) } \\
\downarrow \text { Reversal learning (Water Y-maze) } \\
\uparrow \text { Social aggressions (only in males) } \\
=\text { No effects (Locomotion, Social approach, PPI, } \\
\text { Allogrooming, Sniffing) }\end{array}$ & Norton et al. ${ }^{169}$ \\
\hline $\begin{array}{l}300 \mathrm{mg} / \mathrm{kg} \text { s.c. } \\
\text { (twice/day on P2-P3 and } \\
\text { once at P4) }\end{array}$ & P2-P4 & Sprague-Dawley rats & $\begin{array}{l}\uparrow \text { Exploration (OF) and } \downarrow \text { Entries and Time in } \\
\text { open arms (EPM) } \\
\downarrow \text { Social preference and interaction (Ttime spent, } \\
\text { Sniffing, Grooming, Mounting, Crawling) } \\
=\text { No effects (Passive avoidance) }\end{array}$ & Mony et al. ${ }^{171}$ \\
\hline 150 mg/kg/day i.p. & P6-P20 & Sprague-Dawley rats & $\begin{array}{l}\uparrow \text { Delay in eye opening } \\
\downarrow \text { Social play (rough-and-tumble) } \\
\uparrow \text { Cue-dependent reward learning }\end{array}$ & Chomiak et al. ${ }^{168}$ \\
\hline
\end{tabular}

In the studies where both sexes were analyzed, the sex-specific effects observed are indicated.

OF Open field, EPM Elevated plus maze, PPI Prepulse inhibition, MWM Morris water maze, NSF Novelty-suppressed feeding test, TST Tail suspension test, FST Forcedswim test, NOR Novel object recognition.

Social behaviors appeared to be markedly affected by prenatal VPA in various mouse/rat strains, indicating a highly consistent reduction in the number of ultrasonic vocalizations and social interactions (e.g., nose pokes, approaches, etc...), accompanied by a diminished juvenile social play, and limited interest for novel conspecifics $^{134,135,139,140,142,143,145-147,149,150,153,154,157-164}$. However, several studies failed to replicate some of these 
effects $^{136,137,151}$. On the other hand, and related to the social deficits observed, a decreased olfactory motivation and sensorimotor capacity were found in VPA-exposed mice ${ }^{134,139,142,145,155}$ (Table 3). Additionally, sex-specific aggressive and defensive strategies in social settings appeared to be affected by the VPA exposure, switching from a defensive tactic to a more aggressive one ${ }^{161}$. Furthermore, enhanced freezing and startle responses were described in different fear-conditioning paradigms after VPA treatment ${ }^{142,153,154,157,160,165,166}$ (Table 3).

Certain cognitive aspects have been described to be altered in VPA gestational models, though the behavioral outcomes were less consistent. Thus, several studies reported either deficits ${ }^{133,135,137}$ or improvements in spatial learning ${ }^{146}$, while others could not reproduce these effects $^{142,143}$. Similarly, evaluation of exploration time of a novel object showed that VPA treatment increased the interaction to familiar objects ${ }^{144,148}$, though other researchers could not replicate these findings ${ }^{147,152,154}$. Additionally, deficits in working memory ${ }^{146,147}$, temporal accuracy $^{167}$, attentional, and negative reinforcement learning tasks ${ }^{148,164}$ were also reported (Table 3).

There are fewer studies applying postnatal exposures to VPA, having in general, less robust behavioral effects (Table 3). VPA treatment somewhere during the first 2 postnatal weeks produces a delayed neurological maturation ${ }^{133,168}$, without any apparent locomotor effects ${ }^{133,169}$, though others observed an enhanced locomotion ${ }^{170,171}$. On the other hand, changes on anxiety behaviors were described in rats $^{171}$, but not in mice ${ }^{169}$ (Table 3).

Social behaviors were shown to be affected by postnatal exposure to VPA in rats and mice ${ }^{168,170,171}$, though others could not replicate some of these findings ${ }^{169}$. In the same conditions, higher levels of social aggression were found ${ }^{169}$ (Table 3).

Several cognitive aspects appeared to be affected in these models, including deficits in spatial ${ }^{133}$ and reversal learning ${ }^{169}$, accompanied by enhanced cue-dependent reward learning ${ }^{168}$. Additionally, other studies described longer latencies in a passive avoidance paradigm in mice $^{133}$, while others failed to reproduce some of these effects in rats ${ }^{171}$ (Table 3).

\section{Neural mechanisms engaged in the rodent models of early-life exposure}

In the last decade, many preclinical studies have contributed to our understanding of the possible molecular, cellular and circuit mechanisms implicated in the neurodevelopmental vulnerability to psychiatric conditions. A main concept emerging from those studies is that the ontogenetic occurrence of unique developmental events defines critical periods of plasticity with a maximal sensitivity to environmental functional demands ${ }^{14-16,18}$. Thus, depending on the period when the environmental challenge/perturbation takes place, the long-lasting impact that it will have on the mature brain. In this section, we explore maladaptive neural mechanisms that have been implicated in the behavioral outcomes of the analyzed rodent models, paying special attention to brain regions and neural mechanisms that could be similarly altered across the different models.

\section{Developmental role of 5-HT and Prefrontal circuits}

Perturbation of the 5-HT neural signaling during earlylife has been long associated with developmental origins of several psychiatric conditions, including anxiety, depression, and $\mathrm{ASD}^{43,44,172-176}$. In rodents, activation of 5-HT receptors in different brain regions has been implicated in long-term emotional alterations. Thus, in the early-life stress model of maternal separation, an enhanced adult 5-HT2A/C-mediated prefrontal function was found ${ }^{62}$, while the early postnatal pharmacological blockade of these receptors prevented the emergence of the anxiety phenotype in the same model ${ }^{63}$. Interestingly, the expression of $5-\mathrm{HT} 2 \mathrm{~A} / \mathrm{C}$ receptors appeared to be substantially modified by prenatal stress but not after maternal separation ${ }^{55,63}$. Emotional alterations produced by the postnatal exposure to SSRIs also appear to be mediated, at least in part, by $5-\mathrm{HT} 2 \mathrm{~A} / \mathrm{C}$ receptors. That is, the exposure to 5-HT2A and 5-HT2C antagonists during the early postnatal period prevents the anxiety and depressive-like phenotypes induced by fluoxetine, while the treatment in the same period with agonists of the same receptors produces anxiety ${ }^{104}$.

Other 5-HT receptors such as the 5-HT1A and 5-HT7 were also implicated in the behavioral consequences of early postnatal SSRIs. That is, some of the adult emotional effects induced by postnatal fluoxetine were found to be enhanced by the co-treatment with a 5 -HT1A receptor agonist ${ }^{116}$. More recently, the prefrontal 5-HT7 receptors have been shown to have a crucial developmental role in the emergence of anxiety and depressive-like symptoms in the model of postnatal fluoxetine ${ }^{112}$. Additionally, increased stimulation of 5-HT1A receptors during early postnatal life was also shown to mimic deficits produced by early SSRIs on adult social interactions of relevance to $\mathrm{ASD}^{128}$. On the other hand, in the VPA model, activation of 5-HT1A receptors improves some of the social and cognitive deficits produced in that model ${ }^{166}$.

Accumulating evidence indicates a primordial role of the prefrontal cortex (PFC) in these neurodevelopmental mechanisms. Thus, disruptions of developmental processes in the PFC such as circuit formation/refinement, synaptic connectivity, and oligodendrogenesis/myelinization, have been directly linked to the early vulnerability to stress-related and emotional alterations (Fig. 1). Prenatal stress has been reported to produce a decrease in spine density in mPFC pyramidal neurons ${ }^{48}$. A similar 


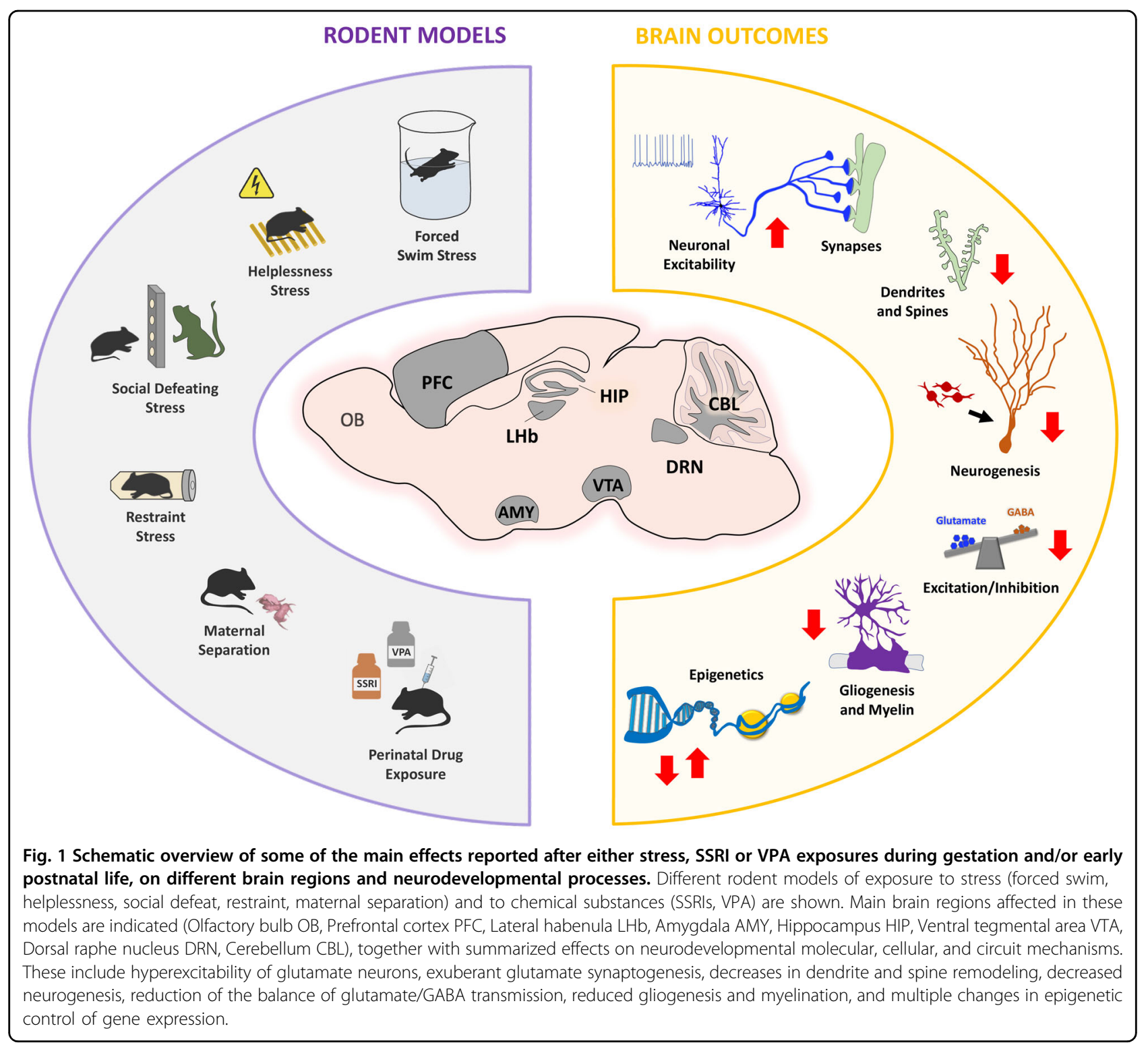

reduction was described in layer $2-3$ mPFC pyramidal cells after postnatal exposure to fluoxetine, accompanied by altered excitability of this neuronal population and exuberant dendritic branching ${ }^{106,115}$. Functional imaging analysis in trumpet-tailed rats subjected to maternal separation stress has shown a global decrease in brain activity in PFC circuits likely engaged in prefrontal-limbic control $^{177}$. Besides, decreases in the excitability of PFC pyramidal neurons have been recently described after maternal separation ${ }^{178}$. Consistent findings were described when analyzing the expression of activity-related immediate early genes in the PFC in the same model, accompanied by a precocious oligodendrocyte differentiation, and hypo-myelination ${ }^{67,179,180}$. In agreement with this, postnatal exposure to the SSRI citalopram, but not the prenatal treatment, was shown to alter the oligodendrocyte morphology and the callosal connectivity ${ }^{126}$.

Recent studies have shown a synaptic hyperconnectivity of corticolimbic circuits such as the PFCto-dorsal raphe nucleus (DRN) one, after postnatal exposure to fluoxetine during the early postnatal period $^{111}$. Furthermore, these changes were found to be mediated by the developmental 5-HT signaling through the 5-HT7 receptors in the $\mathrm{PFC}^{112}$. Importantly, reciprocal circuits connect the PFC to DRN 5-HT neurons, and these pathways have a crucial role in controlling stress-coping strategies and emotional responses throughout life ${ }^{111,181,182}$.

Direct inhibition of the activity of DRN 5-HT neurons using chemogenetic tools has been shown to prevent the emergence of the emotional alterations produced by 
postnatal fluoxetine ${ }^{107}$. On the other hand, the early-life treatment with another SSRI (i.e., citalopram), was shown to reduce the 5-HT synthesis and its forebrain release ${ }^{123}$. Additionally, maternal separation reduces the firing activity of DRN 5-HT neurons ${ }^{183}$. Interestingly, gestational exposure to VPA was reported to delay the migration and differentiation of developing DRN 5-HT neurons ${ }^{184}$.

Altogether, this evidence indicates a complex role of the developing 5-HT system and its targeted neural circuits, in the detrimental emotional effects produced by early-life exposures.

\section{Other neural circuits implicated}

Other studies have implicated other brain structures such as the ventral tegmental area (VTA) and lateral habenula $(\mathrm{LHb})$, in the emotional vulnerability during early-life $^{64,82}$ (Fig. 1). There, genetic invalidation of an early transcriptional program in the VTA was sufficient to replicate the life-long susceptibility to stress observed after maternal separation ${ }^{64}$. Furthermore, a recent study using the same model showed enhancements in the excitability of VTA dopamine neurons and their excitatory synaptic inputs ${ }^{185}$. In another study, researchers showed that limiting the hyperactivity of LHb output neurons relieves the depressive-like symptoms caused by maternal separation ${ }^{82}$. Interestingly, both VTA and LHb neurons are interconnected, and receive dense 5-HT afferents ${ }^{186}$, and in turn, send projections back to DRN neurons ${ }^{187,188}$.

The hippocampus appeared to be more robustly affected in preclinical models using either gestational or precocious early postnatal exposures. Thus, alterations in neurogenesis were found among the different preclinical models $^{52,59,81,110,189}$ (Fig. 1). Specifically, changes in the survival of newborn cells in the dentate gyrus of the hippocampus ${ }^{52,59,81,189}$ and alterations in the expression of neurogenic modulators such as brain-derived neurotrophic factor $(\mathrm{BDNF})^{52,110}$, have been consistently reported after either prenatal or early postnatal stress protocols. Similarly, effects on the hippocampal neurogenesis and BDNF expression levels were also described after maternal separation, SSRI and VPA postnatal exposures ${ }^{108,110,113,189-191}$. Interestingly, postnatal SSRI exposure reverses alterations on hippocampal neurogenesis produced by prenatal maternal stress ${ }^{189}$.

Alterations in the synaptic morphology and function of the hippocampus were implicated in the models of prenatal exposures to VPA and stress ${ }^{53,135,159,192}$. Interestingly, in the stress model, postnatal treatment with SSRIs restores the normal density of dendritic spines and glutamate synapses ${ }^{119}$. In this last model, altered formation and maintenance of the hippocampal perineuronal net has been recently shown after SSRI exposure ${ }^{193}$.
Furthermore, an altered synaptic development of glutamate/GABA transmission systems has been also described in the PFC, after gestational exposures to SSRIs or $\mathrm{VPA}^{48,99,135,144,159,192}$ (Fig. 1). In addition, these changes were accompanied by a delayed neuronal migration followed by a precocious neuronal maturation, and longstanding modifications in cortical thickness ${ }^{137,144,168}$. Interestingly, cortical modifications on dendritic spines and neuronal morphology were also observed after postnatal exposure to $\mathrm{VPA}^{169}$ (Fig. 1), likely reflecting the protracted developmental period of frontocortical circuits. Lastly, at the system level, the early-life stress experience of maternal separation was shown to perturb the communication within the network engaging hippocampal and PFC circuits ${ }^{194}$.

Other studies point out to the amygdala as a key neural substrate involved in the effects of maternal separation and in utero VPA exposure (Fig. 1). These investigations showed a reduced functional connectivity between the basolateral amygdaloid nucleus (BLA) and the PFC after maternal separation ${ }^{195}$, in agreement with previous imaging findings in depressive patients ${ }^{196,197}$. On the other hand, enhancements of the neuronal excitability and glutamate transmission in the amygdala have been reported in the VPA model ${ }^{142,153}$. Besides, similar findings were described in the same model in frontocortical circuits $^{158,165,198,199}$ (Fig. 1). Interestingly, treatment with a metabotropic glutamate receptor 5 (mGluR5) antagonist rescued some of the social behavioral deficits observed in the VPA model ${ }^{138}$. Additionally, changes on GABAergic neurochemical markers and modifications on the neuronal/glial cytoarchitecture, have been also reported in the amygdala and cerebellum, after prenatal exposure to VPA $^{135,156,200}$.

\section{Epigenetic mechanisms}

Other lines of evidence indicate an important role for epigenetic control of gene expression in the neurodevelopmental mechanisms at play in these preclinical models (Fig. 1). For instance, a transcriptional disruption of genes involved in developmental and immune gene networks has been described in the amygdala after VPA exposure $^{157}$. In other studies, researchers found that acetylation regulation of hippocampal gene expression by the histone deacetylase (HDAC) 4 is crucially involved in the adult emotional alterations caused by postnatal SSRIs ${ }^{105}$. Consistent with its relevance, a decreased expression of several members of the HDAC family was reported in frontocortical regions including the PFC of maternallyseparated rats and mice ${ }^{180,201}$. Furthermore, in one of these studies the authors suggested that this mechanism could be a major contributor to the susceptibility/resilience to early-life stress, and the subsequent efficacy to antidepressant treatments ${ }^{201}$. In utero effects of VPA have 
been directly linked to its actions on the activity of HDACs. Thus, exposure to the HDAC inhibitor trichostatin A, can phenocopy many of the social behavioral deficits observed in the VPA model ${ }^{145}$. Consistently, the prenatal treatment with valpromide, a VPA analog lacking the HDAC's inhibitory activity, failed to reproduce the social interaction deficits ${ }^{137}$.

Methylation of promoter regions has been also implicated in the effects of SSRIs during pregnancy and lactation $^{98,109}$. These investigations showed long-lasting changes in methylation levels of multiple genes in the hippocampus and cortex, including the Bdnf gene ${ }^{98,109}$. Interestingly, chromatin remodeling and increased methylation levels in the PFC were reported, after either gestational stress ${ }^{48}$ or VPA exposure ${ }^{202}$. Lastly, the transgenerational epigenetic inheritance of VPA-induced imbalance in excitatory/inhibitory transmission in the frontal cortex has been recently demonstrated ${ }^{203}$, illustrating the rather complex repertoire of neurodevelopmental mechanisms that could be engaged in the different preclinical models of exposure.

\section{Translational Aspects and Concluding Remarks}

Rodent models have been very useful to investigate the mechanisms implicated in the developmental vulnerability to psychiatric disorders. Thus, preclinical research surveyed in this review allows the identification of neural substrates and neurobiological mechanisms impacted by early-life environmental exposures. Importantly, many of these findings may directly relate to what occurs in the complex human psychopathology. However, other biological processes linked to gene regulation and its possible interaction to environmental conditions, is growingly emerging as crucial actors involved in neuropsychiatric disorders. For instance, investigations in rodents with reduced 5-HT synthesis have shown a differential impact on the DRN 5-HT system of maternal separation $^{204}$, while reduction of the 5-HT transporter, SERT, leads to an enhanced anhedonia under similar stress conditions ${ }^{205}$. Furthermore, combination of stress exposure and postnatal SSRI treatment in dams alters affective susceptibility of the offspring in a SERTdependent manner ${ }^{206}$. Conversely, behavioral alterations produced by in utero VPA exposure were not affected by the presence of SERT ${ }^{155}$. On the other hand, rats with reduced SERT expression, and a previous history of maternal separation, showed improvements in stress-coping responses ${ }^{207}$. Interestingly, in utero exposure to citalopram mitigates the detrimental effects of maternal stress on the fetal forebrain development, and these changes are thought to be mediated by normalizing brain 5-HT levels ${ }^{88}$.

Human studies have shown that gestational exposure to SSRIs is associated with adverse neonatal outcomes that can be moderated by the SERT promoter polymorphism of the infants ${ }^{20}$. Moreover, methylation of the SERT promoter can influence the soothability of infants that had exposition to SSRIs during the gestation ${ }^{208}$. Additionally, the hyperserotonemia and several stereotypical behavioral outcomes present in ASD patients can be replicated in mice that express a hyperfunctional SERT variant ${ }^{209,210}$.

A critical point to be considered when analyzing the risk of exposure to SSRIs in pregnant women is the psychopathological state of the future mother. Evidence indicates that SSRI treatment in depressed mothers can prevent the modifications in brain's connectivity produced in newborns that are exposed to unmedicated depressive mothers ${ }^{211}$. In addition, other studies have shown that adverse effects produced by prenatal maternal depression on infant's problematic temperament can be amplified by a concurrent prenatal traumatic stress ${ }^{212}$.

In the case of VPA, human evidence supports only a poor interaction between the effects of prenatal exposure to VPA and maternal mental health. Thus, a very recent nationwide population-based analysis has shown that in utero exposure to VPA is associated with an increased risk of neurodevelopmental mental and behavioral disorders in exposed children ${ }^{213}$. Moreover, these effects were stronger when exposures occurred during the second and third trimesters of pregnancy. However, these findings were not affected by the mother's mental health ${ }^{213}$.

Future investigations need to consider neurodevelopmental regulatory mechanisms as well as other biological factors, such as the neuroinflammatory and hormonal contexts, that could influence the brain's homeostatic capacity to mitigate early-life environmental perturbations. Altogether, these further considerations will improve understanding of how developmental maladaptive mechanisms could increase the risk of vulnerability to mental disorders.

\begin{abstract}
Acknowledgements
The authors are grateful to Drs. Delfina M. Romero, Anne Teissier, and Patricia Gaspar for their insightful comments on the paper. Our research is supported by the Consejo Nacional de Investigaciones Científicas y Técnicas (CONICET), the International Brain Research Organization (IBRO), and the CAEN program of the International Society for Neurochemistry. T.S.A. and C.V.A. are supported by Doctoral Fellowships from CONICET and M.S-R. is an investigator from the same institution.
\end{abstract}

Conflict of interest

The author declares no competing interests.

Publisher's note

Springer Nature remains neutral with regard to jurisdictional claims in published maps and institutional affiliations.

Received: 20 October 2020 Revised: 16 April 2021 Accepted: 21 April 2021 Published online: 11 May 2021 


\section{References}

1. GBD 2017 Disease and Injury Incidence and Prevalence Collaborators. Global, regional, and national incidence, prevalence, and years lived with disability for 354 diseases and injuries for 195 countries and territories, 1990-2017: a systematic analysis for the Global Burden of Disease Study 2017. Lancet Lond. Engl. 392, 1789-1858 (2018).

2. Friedrich, M. J. Depression is the leading cause of disability around the world. JAMA 317, 1517 (2017).

3. Kaufman, J. \& Charney, D. Effects of early stress on brain structure and function: implications for understanding the relationship between child maltreatment and depression. Dev. Psychopathol. 13, 451-471 (2001).

4. Kessler, R. C. et al. Childhood adversities and adult psychopathology in the WHO World Mental Health Surveys. Br. J. Psychiatry J. Ment. Sci. 197, 378-385 (2010).

5. Bale, T. L. et al. Early life programming and neurodevelopmental disorders. Biol. Psychiatry 68, 314-319 (2010).

6. Teicher, M. H., Samson, J. A., Anderson, C. M. \& Ohashi, K. The effects of childhood maltreatment on brain structure, function and connectivity. Nat. Rev. Neurosci. 17, 652-666 (2016).

7. Lippard, E. T. C. \& Nemeroff, C. B. The devastating clinical consequences of child abuse and neglect: increased disease vulnerability and poor treatment response in mood disorders. Am. J. Psychiatry 177, 20-36 (2020).

8. Teicher, M. H. \& Samson, J. A. Childhood maltreatment and psychopathology: a case for ecophenotypic variants as clinically and neurobiologically distinct subtypes. Am. J. Psychiatry 170, 1114-1133 (2013).

9. McCrory, E. J., Gerin, M. I. \& Viding, E. Annual research review: childhood maltreatment, latent vulnerability and the shift to preventative psychiatrythe contribution of functional brain imaging. J. Child Psychol. Psychiatry $\mathbf{5 8}$ 338-357 (2017).

10. Homberg, J. R., Schubert, D. \& Gaspar, P. New perspectives on the neurodevelopmental effects of SSRIs. Trends Pharmacol. Sci. 31, 60-65 (2010).

11. Kolb, B. et al. Experience and the developing prefrontal cortex. Proc. Natl Acad. Sci. U.S.A. 109 (Suppl 2), 17186-17193 (2012).

12. Suri, D., Teixeira, C. M., Cagliostro, M. K. C., Mahadevia, D. \& Ansorge, M. S. Monoamine-sensitive developmental periods impacting adult emotional and cognitive behaviors. Neuropsychopharmacology $\mathbf{4 0}$, 88-112 (2015).

13. Nettis, M. A., Pariante, C. M. \& Mondelli, V. Early-life adversity, systemic inflammation and comorbid physical and psychiatric illnesses of adult life. Curr. Top. Behav. Neurosci. 44, 207-225 (2020).

14. Berardi, N., Pizzorusso, T. \& Maffei, L. Critical periods during sensory development. Curr. Opin. Neurobiol. 10, 138-145 (2000)

15. Hensch, T. K. Critical period plasticity in local cortical circuits. Nat. Rev. Neurosci. 6, 877-888 (2005).

16. Marín, O. Developmental timing and critical windows for the treatment of psychiatric disorders. Nat. Med. 22, 1229-1238 (2016).

17. Hensch, T. K. The power of the infant brain. Sci. Am. 314, 64-69 (2016).

18. Teissier, A., Soiza-Reilly, M. \& Gaspar, P. Refining the role of 5-HT in postnatal development of brain circuits. Front. Cell. Neurosci. 11, 139 (2017).

19. Moses-Kolko, E. L. et al. Neonatal signs after late in utero exposure to serotonin reuptake inhibitors: literature review and implications for clinical applications. JAMA 293, 2372-2383 (2005)

20. Oberlander, T. F. et al. Infant serotonin transporter (SLC6A4) promoter genotype is associated with adverse neonatal outcomes after prenatal exposure to serotonin reuptake inhibitor medications. Mol. Psychiatry 13, 65-73 (2008).

21. Hanley, G. E., Brain, U. \& Oberlander, T. F. Prenatal exposure to serotonin reuptake inhibitor antidepressants and childhood behavior. Pediatr. Res. 78, 174-180 (2015).

22. Malm, H. et al. Gestational exposure to selective serotonin reuptake inhibitors and offspring psychiatric disorders: a national register-based study. J. Am. Acad. Child Adolesc. Psychiatry 55, 359-366 (2016).

23. Brown, A. S. et al. Association of selective serotonin reuptake inhibitor exposure during pregnancy with speech, scholastic, and motor disorders in offspring. JAMA Psychiatry 73, 1163-1170 (2016).

24. Rotem-Kohavi, N. \& Oberlander, T. F. Variations in neurodevelopmental outcomes in children with prenatal SSRI antidepressant exposure. Birth Defects Res. 109, 909-923 (2017).

25. Lugo-Candelas, $\mathrm{C}$. et al. Associations between brain structure and connectivity in infants and exposure to selective serotonin reuptake inhibitors during pregnancy. JAMA Pediatr. 172, 525-533 (2018).
26. Erickson, N. L. et al. Prenatal SSRI antidepressant use and maternal internalizing symptoms during pregnancy and postpartum: Exploring effects on infant temperament trajectories for boys and girls. J. Affect Disord. 258, 179-194 (2019).

27. Croen, L. A., Grether, J. K., Yoshida, C. K., Odouli, R. \& Hendrick, V. Antidepressant use during pregnancy and childhood autism spectrum disorders. Arch. Gen. Psychiatry 68, 1104-1112 (2011).

28. Hviid, A., Melbye, M. \& Pasternak, B. Use of selective serotonin reuptake inhibitors during pregnancy and risk of autism. N. Engl. J. Med. 369 2406-2415 (2013).

29. Harrington, R. A., Lee, L.-C., Crum, R. M., Zimmerman, A. W. \& Hertz-Picciotto, I. Prenatal SSRI use and offspring with autism spectrum disorder or developmental delay. Pediatrics 133, e1241-e1248 (2014).

30. Boukhris, T., Sheehy, O., Mottron, L. \& Bérard, A. Antidepressant use during pregnancy and the risk of autism spectrum disorder in children. JAMA Pediatr. 170, 117-124 (2016).

31. Andalib, S. et al. Maternal SSRI exposure increases the risk of autistic offspring: a meta-analysis and systematic review. Eur. Psychiatry 45, 161-166 (2017).

32. Kim, J. Y. et al. Environmental risk factors and biomarkers for autism spectrum disorder: an umbrella review of the evidence. Lancet Psychiatry 6, 590-600 (2019).

33. Lai, M.-C. et al. Prevalence of co-occurring mental health diagnoses in the autism population: a systematic review and meta-analysis. Lancet Psychiatry 6, 819-829 (2019).

34. Hossain, M. M. et al. Prevalence of comorbid psychiatric disorders among people with autism spectrum disorder: an umbrella review of systematic reviews and meta-analyses. Psychiatry Res. 287, 112922 (2020).

35. Heim, C. \& Nemeroff, C. B. The role of childhood trauma in the neurobiology of mood and anxiety disorders: preclinical and clinical studies. Biol. Psychiatry 49, 1023-1039 (2001).

36. Penza, K. M., Heim, C. \& Nemeroff, C. B. Neurobiological effects of childhood abuse: implications for the pathophysiology of depression and anxiety. Arch Women's Ment. Health 6, 15-22 (2003).

37. Gingrich, J. A. et al. New insights into how serotonin selective reuptake inhibitors shape the developing. Brain. Birth Defects Res 109, 924-932 (2017).

38. Careaga, M., Murai, T. \& Bauman, M. D. Maternal immune activation and autism spectrum disorder: from rodents to nonhuman and human primates. Biol. Psychiatry 81, 391-401 (2017).

39. Nicolini, C. \& Fahnestock, M. The valproic acid-induced rodent model of autism. Exp. Neurol. 299, 217-227 (2018).

40. Tartaglione, A. M., Schiavi, S., Calamandrei, G. \& Trezza, V. Prenatal valproate in rodents as a tool to understand the neural underpinnings of social dysfunctions in autism spectrum disorder. Neuropharmacology 159, 107477 (2019).

41. Meyer, H. C. \& Lee, F. S. Translating developmental neuroscience to understand risk for psychiatric disorders. Am. J. Psychiatry 176, 179-185 (2019).

42. Kinast, K., Peeters, D., Kolk, S. M., Schubert, D. \& Homberg, J. R. Genetic and pharmacological manipulations of the serotonergic system in early life: neurodevelopmental underpinnings of autism-related behavior. Front. Cell. Neurosci. 7, 72 (2013).

43. Hanswijk, S. I. et al. Gestational factors throughout fetal neurodevelopment: the serotonin link. Int. J. Mol. Sci. 21, 5850 (2020)

44. Tiwari, P. et al. GPCR signaling: role in mediating the effects of early adversity in psychiatric disorders. FEBS J. 288, 2602-2621 (2021)

45. Estanislau, C. \& Morato, S. Behavior ontogeny in the elevated plus-maze: prenatal stress effects. Int. J. Dev. Neurosci. 24, 255-262 (2006).

46. Miyagawa, K., Tsuji, M., Fujimori, K., Saito, Y. \& Takeda, H. Prenatal stress induces anxiety-like behavior together with the disruption of central serotonin neurons in mice. Neurosci. Res. 70, 111-117 (2011).

47. Miyagawa, K., Tsuji, M., Ishii, D., Takeda, K. \& Takeda, H. Prenatal stress induces vulnerability to stress together with the disruption of central serotonin neurons in mice. Behav. Brain Res. 277, 228-236 (2015).

48. Dong, E., Guidotti, A., Zhang, H. \& Pandey, S. C. Prenatal stress leads to chromatin and synaptic remodeling and excessive alcohol intake comorbid with anxiety-like behaviors in adult offspring. Neuropharmacology 140, 76-85 (2018).

49. Enayati, M., Mosaferi, B., Homberg, J. R., Diniz, D. M. \& Salari, A.-A. Prenatal maternal stress alters depression-related symptoms in a strain - and sex-dependent manner in rodent offspring. Life Sci. 251, 117597 (2020). 
50. Richardson, H. N., Zorrilla, E. P., Mandyam, C. D. \& Rivier, C. L. Exposure to repetitive versus varied stress during prenatal development generates two distinct anxiogenic and neuroendocrine profiles in adulthood. Endocrinology 147, 2506-2517 (2006)

51. Pallarés, M. E., Scacchi Bernasconi, P. A., Feleder, C. \& Cutrera, R. A. Effects of prenatal stress on motor performance and anxiety behavior in Swiss mice. Physiol. Behav. 92, 951-956 (2007).

52. Zuena, A. R. et al. Prenatal restraint stress generates two distinct behavioral and neurochemical profiles in male and female rats. PloS ONE 3, e2170 (2008).

53. Laloux, C. et al. Anxiety-like behaviour and associated neurochemical and endocrinological alterations in male pups exposed to prenatal stress. Psychoneuroendocrinology 37, 1646-1658 (2012).

54. Van den Hove, D. L. A. et al. Prenatal stress and subsequent exposure to chronic mild stress in rats; interdependent effects on emotional behavior and the serotonergic system. Eur. Neuropsychopharmacol. 24, 595-607 (2014).

55. Akatsu, S., Ishikawa, C., Takemura, K., Ohtani, A. \& Shiga, T. Effects of prenatal stress and neonatal handling on anxiety, spatial learning and serotonergic system of male offspring mice. Neurosci. Res. 101, 15-23 (2015).

56. Soliani, F. C. et al. Unpredictable chronic prenatal stress and manifestation of generalized anxiety and panic in rat's offspring. Prog. Neuropsychopharmacol. Biol. Psychiatry 85, 89-97 (2018).

57. Iturra-Mena, A. M., Arriagada-Solimano, M., Luttecke-Anders, A. \& DagninoSubiabre, A. Effects of prenatal stress on anxiety- and depressive-like behaviours are sex-specific in prepubertal rats. J. Neuroendocrinol. 30, e12609 (2018).

58. Poltyrev, T., Gorodetsky, E., Bejar, C., Schorer-Apelbaum, D. \& Weinstock, M. Effect of chronic treatment with ladostigil (TV-3326) on anxiogenic and depressive-like behaviour and on activity of the hypothalamicpituitary-adrenal axis in male and female prenatally stressed rats. Psychopharmacology 181, 118-125 (2005).

59. Barbie-Shoshani, Y., Shoham, S., Bejar, C. \& Weinstock, M. Sex-specific effects of prenatal stress on memory and markers of neuronal activity in juvenile rats. Dev. Neurosci. 38, 206-219 (2016).

60. Callaghan, B. L., Sullivan, R. M., Howell, B. \& Tottenham, N. The international society for developmental psychobiology Sackler symposium: early adversity and the maturation of emotion circuits-a cross-species analysis. Dev. Psychobiol. 56, 1635-1650 (2014)

61. George, E. D., Bordner, K. A., Elwafi, H. M. \& Simen, A. A. Maternal separation with early weaning: a novel mouse model of early life neglect. BMC Neurosci. 11, 123 (2010).

62. Benekareddy, M., Goodfellow, N. M., Lambe, E. K. \& Vaidya, V. A. Enhanced function of prefrontal serotonin 5 -HT(2) receptors in a rat model of psychiatric vulnerability. J. Neurosci. 30, 12138-12150 (2010).

63. Benekareddy, M., Vadodaria, K. C., Nair, A. R. \& Vaidya, V. A. Postnatal serotonin type 2 receptor blockade prevents the emergence of anxiety behavior, dysregulated stress-induced immediate early gene responses, and specific transcriptional changes that arise following early life stress. Biol. Psychiatry 70 , 1024-1032 (2011).

64. Peña, C. J. et al. Early life stress confers lifelong stress susceptibility in mice via ventral tegmental area OTX2. Science 356, 1185-1188 (2017).

65. Bondar, N. P., Lepeshko, A. A. \& Reshetnikov, V. V. Effects of early-life stress on social and anxiety-like behaviors in adult mice: sex-specific effects. Behav. Neurol. 2018, 1538931 (2018).

66. Park, S.-S., Park, H.-S., Kim, C.-J., Baek, S.-S. \& Kim, T.-W. Exercise attenuates maternal separation-induced mood disorder-like behaviors by enhancing mitochondrial functions and neuroplasticity in the dorsal raphe. Behav. Brain Res. 372, 112049 (2019)

67. Teissier, A. et al. Early-life stress impairs postnatal oligodendrogenesis and adult emotional behaviour through activity-dependent mechanisms. Mol. Psychiatry 25, 1159-1174 (2020).

68. Farkas, J. et al. Effects of maternal separation on the neurobehavioral development of newborn Wistar rats. Brain Res. Bull. 79, 208-214 (2009).

69. Own, L. S. \& Patel, P. D. Maternal behavior and offspring resiliency to maternal separation in C57BI/6 mice. Horm. Behav. 63, 411-417 (2013).

70. Bailoo, J. D., Jordan, R. L., Garza, X. J. \& Tyler, A. N. Brief and long periods of maternal separation affect maternal behavior and offspring behavioral development in C57BL/6 mice. Dev. Psychobiol. 56, 674-685 (2014).
71. Rana, S., Pugh, P. C., Jackson, N., Clinton, S. M. \& Kerman, I. A. Inborn stress reactivity shapes adult behavioral consequences of early-life maternal separation stress. Neurosci. Lett. 584, 146-150 (2015).

72. Qin, X. et al. Moderate maternal separation mitigates the altered synaptic transmission and neuronal activation in amygdala by chronic stress in adult mice. Mol. Brain 12, 111 (2019).

73. Rice, C. J., Sandman, C. A., Lenjavi, M. R. \& Baram, T. Z. A novel mouse model for acute and long-lasting consequences of early life stress. Endocrinology 149, 4892-4900 (2008).

74. Yang, X.-D. et al. Stress during a critical postnatal period induces regionspecific structural abnormalities and dysfunction of the prefrontal cortex via CRF1. Neuropsychopharmacology. 40, 1203-1215 (2015).

75. Gallo, M. et al. Limited bedding and nesting induces maternal behavior resembling both hypervigilance and abuse. Front. Behav. Neurosci. 13, 167 (2019).

76. Uhelski, M. L. \& Fuchs, P. N. Maternal separation stress leads to enhanced emotional responses to noxious stimuli in adult rats. Behav. Brain Res. 212, 208-212 (2010).

77. Roque, S., Mesquita, A. R., Palha, J. A., Sousa, N. \& Correia-Neves, M. The behavioral and immunological impact of maternal separation: a matter of timing. Front. Behav. Neurosci. 8, 192 (2014).

78. Kambali, M. Y., Anshu, K., Kutty, B. M., Muddashetty, R. S. \& Laxmi, T. R. Effect of early maternal separation stress on attention, spatial learning and social interaction behaviour. Exp. Brain Res. 237, 1993-2010 (2019).

79. Shin, S. Y., Han, S. H., Woo, R.-S., Jang, S. H. \& Min, S. S. Adolescent mice show anxiety- and aggressive-like behavior and the reduction of long-term potentiation in mossy fiber-CA3 synapses after neonatal maternal separation. Neuroscience 316, 221-231 (2016).

80. Wang, D., Levine, J. L. S., Avila-Quintero, V., Bloch, M. \& Kaffman, A. Systematic review and meta-analysis: effects of maternal separation on anxiety-like behavior in rodents. Transl. Psychiatry 10, 174 (2020).

81. Naninck, E. F. G. et al. Chronic early life stress alters developmental and adult neurogenesis and impairs cognitive function in mice. Hippocampus 25, 309-328 (2015).

82. Tchenio, A., Lecca, S., Valentinova, K. \& Mameli, M. Limiting habenular hyperactivity ameliorates maternal separation-driven depressive-like symptoms. Nat. Commun. 8, 1135 (2017).

83. Thomas, A. W., Caporale, N., Wu, C. \& Wilbrecht, L. Early maternal separation impacts cognitive flexibility at the age of first independence in mice. Dev. Cogn. Neurosci. 18, 49-56 (2016).

84. Holland, F. H., Ganguly, P., Potter, D. N., Chartoff, E. H. \& Brenhouse, H. C. Early life stress disrupts social behavior and prefrontal cortex parvalbumin interneurons at an earlier time-point in females than in males. Neurosci. Lett. $\mathbf{5 6 6}$ 131-136 (2014).

85. Gardner, K. L., Thrivikraman, K. V., Lightman, S. L., Plotsky, P. M. \& Lowry, C. A. Early life experience alters behavior during social defeat: focus on serotonergic systems. Neuroscience 136, 181-191 (2005).

86. Litvin, Y. et al. Maternal separation modulates short-term behavioral and physiological indices of the stress response. Horm. Behav. 58, 241-249 (2010).

87. Johannessen, C. U. Mechanisms of action of valproate: a commentatory. Neurochem Int. 37, 103-110 (2000).

88. Velasquez, J. C. et al. In Utero exposure to citalopram mitigates maternal stress effects on fetal brain development. ACS Chem. Neurosci. 10, 3307-3317 (2019).

89. Harwood, A. J. Neurodevelopment and mood stabilizers. Curr. Mol. Med. 3 472-482 (2003).

90. Ramsteijn, A. S. et al. Perinatal selective serotonin reuptake inhibitor exposure and behavioral outcomes: A systematic review and meta-analyses of animal studies. Neurosci. Biobehav. Rev. 114, 53-69 (2020).

91. Kroeze, Y. et al. Perinatal reduction of functional serotonin transporters results in developmental delay. Neuropharmacology 109, 96-111 (2016).

92. Noorlander, C. W. et al. Modulation of serotonin transporter function during fetal development causes dilated heart cardiomyopathy and lifelong behavioral abnormalities. PloS ONE 3, e2782 (2008).

93. Smit-Rigter, L. A. et al. Prenatal fluoxetine exposure induces life-long serotonin $5-\mathrm{HT}_{3}$ receptor-dependent cortical abnormalities and anxiety-like behaviour. Neuropharmacology 62, 865-870 (2012).

94. McAllister, B. B., Kiryanova, V. \& Dyck, R. H. Behavioural outcomes of perinatal maternal fluoxetine treatment. Neuroscience 226, 356-366 (2012). 
95. Kiryanova, V. \& Dyck, R. H. Increased aggression, improved spatial memory, and reduced anxiety-like behaviour in adult male mice exposed to fluoxetine early in life. Dev. Neurosci. 36, 396-408 (2014).

96. Kiryanova, V., Meunier, S. J., Vecchiarelli, H. A., Hill, M. N. \& Dyck, R. H. Effects of maternal stress and perinatal fluoxetine exposure on behavioral outcomes of adult male offspring. Neuroscience 320, 281-296 (2016).

97. Olivier, J. D. A. et al. Fluoxetine administration to pregnant rats increases anxiety-related behavior in the offspring. Psychopharmacology 217, 419-432 (2011).

98. Toffoli, L. V. et al. Maternal exposure to fluoxetine during gestation and lactation affects the DNA methylation programming of rat's offspring: modulation by folic acid supplementation. Behav. Brain Res. 265, 142-147 (2014).

99. Millard, S. J., Lum, J. S., Fernandez, F., Weston-Green, K. \& Newell, K. A. Perinatal exposure to fluoxetine increases anxiety- and depressive-like behaviours and alters glutamatergic markers in the prefrontal cortex and hippocampus of male adolescent rats: a comparison between Sprague-Dawley rats and the Wistar-Kyoto rat model of depression. J. Psychopharmacol. 33, 230-243 (2019).

100. Svirsky, N., Levy, S. \& Avitsur, R. Prenatal exposure to selective serotonin reuptake inhibitors (SSRI) increases aggression and modulates maternal behavior in offspring mice. Dev. Psychobiol. 58, 71-82 (2016).

101. Gemmel, M. et al. Perinatal fluoxetine has enduring sexually differentiated effects on neurobehavioral outcomes related to social behaviors. Neuropharmacology 144, 70-81 (2019).

102. Heinla, I., Heijkoop, R., Houwing, D. J., Olivier, J. D. A. \& Snoeren, E. M. S. Thirdparty prosocial behavior in adult female rats is impaired after perinatal fluoxetine exposure. Physiol. Behav. 222, 112899 (2020).

103. Ansorge, M. S., Zhou, M., Lira, A., Hen, R. \& Gingrich, J. A. Early-life blockade of the 5-HT transporter alters emotional behavior in adult mice. Science $\mathbf{3 0 6}$ 879-881 (2004)

104. Sarkar, A., Chachra, P. \& Vaidya, V. A. Postnatal fluoxetine-evoked anxiety is prevented by concomitant $5-\mathrm{HT} 2 \mathrm{~A} / \mathrm{C}$ receptor blockade and mimicked by postnatal 5-HT2AVC receptor stimulation. Biol. Psychiatry 76, 858-868 (2014).

105. Sarkar, A. et al. Hippocampal HDAC4 contributes to postnatal fluoxetineevoked depression-like behavior. Neuropsychopharmacology 39, 2221-2232 (2014).

106. Rebello, T. J. et al. Postnatal day 2 to 11 constitutes a 5-HT-sensitive period impacting adult mPFC function. J. Neurosci. 34, 12379-12393 (2014).

107. Teissier, A. et al. Activity of raphé serotonergic neurons controls emotional behaviors. Cell Rep. 13, 1965-1976 (2015).

108. Gobinath, A. R., Workman, J. L., Chow, C., Lieblich, S. E. \& Galea, L. A. M. Maternal postpartum corticosterone and fluoxetine differentially affect adult male and female offspring on anxiety-like behavior, stress reactivity, and hippocampal neurogenesis. Neuropharmacology 101, 165-178 (2016).

109. Boulle, F. et al. Developmental fluoxetine exposure increases behavioral despair and alters epigenetic regulation of the hippocampal BDNF gene in adult female offspring. Horm. Behav. 80, 47-57 (2016).

110. Boulle, F. et al. Prenatal stress and early-life exposure to fluoxetine have enduring effects on anxiety and hippocampal BDNF gene expression in adult male offspring. Dev. Psychobiol. 58, 427-438 (2016).

111. Soiza-Reilly, M. et al. SSRIs target prefrontal to raphe circuits during development modulating synaptic connectivity and emotional behavior. Mol. Psychiatry 24, 726-745 (2019).

112. Olusakin, J. et al. Implication of 5-HT7 receptor in prefrontal circuit assembly and detrimental emotional effects of SSRIs during development. Neuropsychopharmacology 45, 2267-2277 (2020).

113. Karpova, N. N., Lindholm, J., Pruunsild, P., Timmusk, T. \& Castrén, E. Longlasting behavioural and molecular alterations induced by early postnatal fluoxetine exposure are restored by chronic fluoxetine treatment in adult mice. Eur. Neuropsychopharmacol. 19, 97-108 (2009).

114. da Silva, A. I. et al. Fluoxetine treatment of rat neonates significantly reduces oxidative stress in the hippocampus and in behavioral indicators of anxiety later in postnatal life. Can. J. Physiol. Pharmacol. 92, 330-337 (2014).

115. Ko, M.-C., Lee, L. J.-H., Li, Y. \& Lee, L.-J. Long-term consequences of neonatal fluoxetine exposure in adult rats. Dev. Neurobiol. 74, 1038-1051 (2014).

116. Ishikawa, C. \& Shiga, T. The postnatal 5-HT1A receptor regulates adult anxiety and depression differently via multiple molecules. Prog. Neuropsychopharmacol. Biol. Psychiatry 78, 66-74 (2017).
117. Lee, L.-J. Neonatal fluoxetine exposure affects the neuronal structure in the somatosensory cortex and somatosensory-related behaviors in adolescent rats. Neurotox. Res. 15, 212-223 (2009).

118. Zimmerberg, B. \& Germeyan, S. C. Effects of neonatal fluoxetine exposure on behavior across development in rats selectively bred for an infantile affective trait. Dev. Psychobiol. 57, 141-152 (2015).

119. Ishiwata, H., Shiga, T. \& Okado, N. Selective serotonin reuptake inhibitor treatment of early postnatal mice reverses their prenatal stress-induced brain dysfunction. Neuroscience 133, 893-901 (2005).

120. Popa, D., Léna, C., Alexandre, C. \& Adrien, J. Lasting syndrome of depression produced by reduction in serotonin uptake during postnatal development: evidence from sleep, stress, and behavior. J. Neurosci. 28, 3546-3554 (2008).

121. Ansorge, M. S., Morelli, E. \& Gingrich, J. A. Inhibition of serotonin but not norepinephrine transport during development produces delayed, persistent perturbations of emotional behaviors in mice. J. Neurosci. 28, 199-207 (2008).

122. Maciag, D., Williams, L., Coppinger, D. \& Paul, I. A. Neonatal citalopram exposure produces lasting changes in behavior which are reversed by adult imipramine treatment. Eur. J. Pharmacol. 532, 265-269 (2006).

123. Maciag, D. et al. Neonatal antidepressant exposure has lasting effects on behavior and serotonin circuitry. Neuropsychopharmacology 31, 47-57 (2006)

124. Harris, S. S., Maciag, D., Simpson, K. L., Lin, R. C. S. \& Paul, I. A. Dose-dependent effects of neonatal SSRI exposure on adult behavior in the rat. Brain Res. 1429, 52-60 (2012).

125. Altieri, S. C. et al. Perinatal vs genetic programming of serotonin states associated with anxiety. Neuropsychopharmacology 40, 1456-1470 (2015).

126. Simpson, K. L. et al. Perinatal antidepressant exposure alters cortical network function in rodents. Proc. Natl Acad. Sci. U.S.A. 108, 18465-18470 (2011).

127. Rodriguez-Porcel, F. et al. Neonatal exposure of rats to antidepressants affects behavioral reactions to novelty and social interactions in a manner analogous to autistic spectrum disorders. Anat. Rec. Hoboken 294, 1726-1735 (2011).

128. Khatri, N., Simpson, K. L., Lin, R. C. S. \& Paul, I. A. Lasting neurobehavioral abnormalities in rats after neonatal activation of serotonin $1 \mathrm{~A}$ and $1 \mathrm{~B}$ receptors: possible mechanisms for serotonin dysfunction in autistic spectrum disorders. Psychopharmacology 231, 1191-1200 (2014).

129. Freund, N., Thompson, B. S., Denormandie, J., Vaccarro, K. \& Andersen, S. L. Windows of vulnerability: maternal separation, age, and fluoxetine on adolescent depressive-like behavior in rats. Neuroscience 249, 88-97 (2013).

130. Rayen, I., van den Hove, D. L., Prickaerts, J., Steinbusch, H. W. \& Pawluski, J. L. Fluoxetine during development reverses the effects of prenatal stress on depressive-like behavior and hippocampal neurogenesis in adolescence. PloS ONE 6, e24003 (2011).

131. Salari, A.-A., Fatehi-Gharehlar, L., Motayagheni, N. \& Homberg, J. R. Fluoxetine normalizes the effects of prenatal maternal stress on depression- and anxietylike behaviors in mouse dams and male offspring. Behav. Brain Res. 311, 354-367 (2016).

132. Zohar, I., Shoham, S. \& Weinstock, M. Perinatal citalopram does not prevent the effect of prenatal stress on anxiety, depressive-like behaviour and serotonergic transmission in adult rat offspring. Eur. J. Neurosci. 43, 590-600 (2016).

133. Wagner, G. C., Reuhl, K. R., Cheh, M., McRae, P. \& Halladay, A. K. A new neurobehavioral model of autism in mice: pre- and postnatal exposure to sodium valproate. J. Autism Dev. Disord. 36, 779-793 (2006).

134. Schneider, T. \& Przewłocki, R. Behavioral alterations in rats prenatally exposed to valproic acid: animal model of autism. Neuropsychopharmacology $\mathbf{3 0}$, 80-89 (2005).

135. Hou, Q. et al. A developmental study of abnormal behaviors and altered GABAergic signaling in the VPA-treated rat model of autism. Front. Behav. Neurosci. 12, 182 (2018)

136. Narita, M. et al. Nonexploratory movement and behavioral alterations in a thalidomide or valproic acid-induced autism model rat. Neurosci. Res. 66, 2-6 (2010).

137. Kataoka, S. et al. Autism-like behaviours with transient histone hyperacetylation in mice treated prenatally with valproic acid. Int J. Neuropsychopharmacol. 16, 91-103 (2013).

138. Mehta, M. V., Gandal, M. J. \& Siegel, S. J. mGluR5-antagonist mediated reversal of elevated stereotyped, repetitive behaviors in the VPA model of autism. PloS ONE 6, e26077 (2011). 
139. Schneider, T., Turczak, J. \& Przewłocki, R. Environmental enrichment reverses behavioral alterations in rats prenatally exposed to valproic acid: issues for a therapeutic approach in autism. Neuropsychopharmacology 31, 36-46 (2006).

140. Schneider, T. et al. Gender-specific behavioral and immunological alterations in an animal model of autism induced by prenatal exposure to valproic acid. Psychoneuroendocrinology 33, 728-740 (2008)

141. Tsujino, N. et al. Abnormality of circadian rhythm accompanied by an increase in frontal cortex serotonin in animal model of autism. Neurosci. Res. 57, 289-295 (2007)

142. Markram, K., Rinaldi, T., La Mendola, D., Sandi, C. \& Markram, H. Abnormal fear conditioning and amygdala processing in an animal model of autism. Neuropsychopharmacology 33, 901-912 (2008).

143. Bambini-Junior, V. et al. Animal model of autism induced by prenatal exposure to valproate: behavioral changes and liver parameters. Brain Res. 1408, 8-16 (2011).

144. Mychasiuk, R., Richards, S., Nakahashi, A., Kolb, B. \& Gibb, R. Effects of rat prenatal exposure to valproic acid on behaviour and neuro-anatomy. Dev. Neurosci. 34, 268-276 (2012).

145. Moldrich, R. X. et al. Inhibition of histone deacetylase in utero causes sociability deficits in postnatal mice. Behav. Brain Res. 257, 253-264 (2013).

146. Edalatmanesh, M. A., Nikfarjam, H., Vafaee, F. \& Moghadas, M. Increased hippocampal cell density and enhanced spatial memory in the valproic acid rat model of autism. Brain Res. 1526, 15-25 (2013).

147. Campolongo, M. et al. Sociability deficits after prenatal exposure to valproic acid are rescued by early social enrichment. Mol. Autism 9, 36 (2018).

148. McKinnell, Z. E., Maze, T., Ramos, A., Challans, B. \& Plakke, B. Valproic acid treated female Long-Evans rats are impaired on attentional set-shifting. Behav. Brain Res. 397, 112966 (2021).

149. Dufour-Rainfray, D. et al. Behavior and serotonergic disorders in rats exposed prenatally to valproate: a model for autism. Neurosci. Lett. 470, 55-59 (2010).

150. Kim, K. C. et al. The critical period of valproate exposure to induce autistic symptoms in Sprague-Dawley rats. Toxicol. Lett. 201, 137-142 (2011).

151. Cohen, O. S., Varlinskaya, E. I., Wilson, C. A., Glatt, S. J. \& Mooney, S. M. Acute prenatal exposure to a moderate dose of valproic acid increases social behavior and alters gene expression in rats. Int J. Dev. Neurosci. 31, 740-750 (2013).

152. Schneider, T., Ziòłkowska, B., Gieryk, A., Tyminska, A. \& Przewłocki, R. Prenatal exposure to valproic acid disturbs the enkephalinergic system functioning, basal hedonic tone, and emotional responses in an animal model of autism. Psychopharmacology 193, 547-555 (2007).

153. Lin, H.-C., Gean, P.-W., Wang, C.-C., Chan, Y.-H. \& Chen, P. S. The amygdala excitatory/inhibitory balance in a valproate-induced rat autism model. PloS ONE 8, e55248 (2013).

154. Banerjee, A. et al. Abnormal emotional learning in a rat model of autism exposed to valproic acid in utero. Front. Behav. Neurosci. 8, 387 (2014).

155. Ellenbroek, B. A., August, C. \& Youn, J. Does prenatal valproate interact with a genetic reduction in the serotonin transporter? A rat study on anxiety and cognition. Front. Neurosci. 10, 424 (2016).

156. Olexová, L., Štefánik, P. \& Kršková, L. Increased anxiety-like behaviour and altered GABAergic system in the amygdala and cerebellum of VPA rats - an animal model of autism. Neurosci. Lett. 629, 9-14 (2016).

157. Barrett, C. E. et al. Developmental disruption of amygdala transcriptome and socioemotional behavior in rats exposed to valproic acid prenatally. Mol. Autism 8, 42 (2017)

158. Roullet, F. I., Wollaston, L., Decatanzaro, D. \& Foster, J. A. Behavioral and molecular changes in the mouse in response to prenatal exposure to the anti-epileptic drug valproic acid. Neuroscience 170, 514-522 (2010).

159. Kim, K. C. et al. Male-specific alteration in excitatory post-synaptic development and social interaction in pre-natal valproic acid exposure model of autism spectrum disorder. J. Neurochem. 124, 832-843 (2013).

160. Favre, M. R. et al. Predictable enriched environment prevents development of hyper-emotionality in the VPA rat model of autism. Front. Neurosci. 9, 127 (2015).

161. Raza, S. et al. Effects of prenatal exposure to valproic acid on the development of juvenile-typical social play in rats. Behav. Pharmacol. 26, 707-719 (2015).

162. Kazlauskas, N., Seiffe, A., Campolongo, M., Zappala, C. \& Depino, A. M. Sexspecific effects of prenatal valproic acid exposure on sociability and neuroinflammation: Relevance for susceptibility and resilience in autism. Psychoneuroendocrinology 110, 104441 (2019).
163. Gzielo, K. et al. Valproic acid exposure impairs ultrasonic communication in infant, adolescent and adult rats. Eur. Neuropsychopharmacol. 41, 52-62 (2020).

164. Wu, M. et al. Abnormal reinforcement learning in a mice model of autism induced by prenatal exposure to valproic acid. Behav. Brain Res. 395, 112836 (2020).

165. Sui, L. \& Chen, M. Prenatal exposure to valproic acid enhances synaptic plasticity in the medial prefrontal cortex and fear memories. Brain Res. Bull. 87, 556-563 (2012).

166. Wang, C.-C. et al. 5-HT1A-receptor agonist modified amygdala activity and amygdala-associated social behavior in a valproate-induced rat autism model. Int J. Neuropsychopharmacol. 16, 2027-2039 (2013).

167. Acosta, J. et al. Deficits in temporal processing in mice prenatally exposed to Valproic Acid. Eur. J. Neurosci. 47, 619-630 (2018).

168. Chomiak, T., Karnik, V., Block, E. \& Hu, B. Altering the trajectory of early postnatal cortical development can lead to structural and behavioural features of autism. BMC Neurosci. 11, 102 (2010).

169. Norton, S. A. et al. Long-lasting behavioral and neuroanatomical effects of postnatal valproic acid treatment. Neuroscience 434, 8-21 (2020).

170. Yochum, C. L., Dowling, P., Reuhl, K. R., Wagner, G. C. \& Ming, X. VPA-induced apoptosis and behavioral deficits in neonatal mice. Brain Res. 1203, 126-132 (2008).

171. Mony, T. J., Lee, J. W., Dreyfus, C., DiCicco-Bloom, E. \& Lee, H. J. Valproic Acid Exposure during Early Postnatal Gliogenesis Leads to Autistic-like Behaviors in Rats. Clin. Psychopharmacol. Neurosci. 14, 338-344 (2016).

172. Hanley, H. G., Stahl, S. M. \& Freedman, D. X. Hyperserotonemia and amine metabolites in autistic and retarded children. Arch. Gen. Psychiatry 34, 521-531 (1977).

173. Lesch, K. P. et al. Association of anxiety-related traits with a polymorphism in the serotonin transporter gene regulatory region. Science 274, 1527-1531 (1996).

174. Hariri, A. R. et al. Serotonin transporter genetic variation and the response of the human amygdala. Science 297, 400-403 (2002).

175. Caspi, A. et al. Influence of life stress on depression: moderation by a polymorphism in the 5-HTT gene. Science 301, 386-389 (2003).

176. Coutinho, A. M. et al. Variants of the serotonin transporter gene (SLC6A4) significantly contribute to hyperserotonemia in autism. Mol. Psychiatry $\mathbf{9}$, 264-271 (2004).

177. Bock, J., Riedel, A. \& Braun, K. Differential changes of metabolic brain activity and interregional functional coupling in prefronto-limbic pathways during different stress conditions: functional imaging in freely behaving rodent pups. Front. Cell. Neurosci. 6, 19 (2012).

178. Sun, X., Zhang, Y., Li, X., Liu, X. \& Qin, C. Early-life neglect alters emotional and cognitive behavior in a sex-dependent manner and reduces glutamatergic neuronal excitability in the prefrontal cortex. Front. Psychiatry 11, 572224 (2020).

179. Sood, A., Pati, S., Bhattacharya, A., Chaudhari, K. \& Vaidya, V. A. Early emergence of altered 5-HT2A receptor-evoked behavior, neural activation and gene expression following maternal separation. Int. J. Dev. Neurosci. 65, 21-28 (2018).

180. Yang, Y. et al. Neonatal maternal separation impairs prefrontal cortical myelination and cognitive functions in rats through activation of Wnt signaling. Cereb. Cortex 27, 2871-2884 (2017).

181. Amat, J. et al. Medial prefrontal cortex determines how stressor controllability affects behavior and dorsal raphe nucleus. Nat. Neurosci. 8 , 365-371 (2005)

182. Warden, M. R. et al. A prefrontal cortex-brainstem neuronal projection that controls response to behavioural challenge. Nature 492, 428-432 (2012).

183. Vilela, F. C. et al. Maternal separation increases pain sensitivity by reducing the activity of serotonergic neurons in the dorsal raphe nucleus and noradrenergic neurons in locus coeruleus. Neurosci. Lett. 748, 135734 (2021).

184. Miyazaki, K., Narita, N. \& Narita, M. Maternal administration of thalidomide or valproic acid causes abnormal serotonergic neurons in the offspring: implication for pathogenesis of autism. Int J. Dev. Neurosci. 23, 287-297 (2005).

185. Spyrka, J. et al. Early life stress-induced alterations in the activity and morphology of ventral tegmental area neurons in female rats. Neurobiol. Stress 13, 100250 (2020).

186. Muzerelle, A., Scotto-Lomassese, S., Bernard, J. F., Soiza-Reilly, M. \& Gaspar, P. Conditional anterograde tracing reveals distinct targeting of individual serotonin cell groups (B5-B9) to the forebrain and brainstem. Brain Struct. Funct. 221, 535-561 (2016) 
187. Soiza-Reilly, M. \& Commons, K. G. Glutamatergic drive of the dorsal raphe nucleus. J. Chem. Neuroanat. 41, 247-255 (2011).

188. Ogawa, S. K., Cohen, J. Y., Hwang, D., Uchida, N. \& Watabe-Uchida, M. Organization of monosynaptic inputs to the serotonin and dopamine neuromodulatory systems. Cell Rep. 8, 1105-1118 (2014).

189. Rayen, I., Gemmel, M., Pauley, G., Steinbusch, H. W. M. \& Pawluski, J. L. Developmental exposure to SSRIs, in addition to maternal stress, has longterm sex-dependent effects on hippocampal plasticity. Psychopharmacology 232, 1231-1244 (2015)

190. Suri, D. et al. Early stress evokes age-dependent biphasic changes in hippocampal neurogenesis, BDNF expression, and cognition. Biol. Psychiatry 73, 658-666 (2013).

191. Wang, C.-Y., Cheng, C.-W., Wang, W.-H., Chen, P.-S. \& Tzeng, S.-F. Postnatal stress induced by injection with valproate leads to developing emotional disorders along with molecular and cellular changes in the hippocampus and amygdala. Mol. Neurobiol. 53, 6774-6785 (2016).

192. Gassowska-Dobrowolska, M. et al. Prenatal exposure to valproic acid affects microglia and synaptic ultrastructure in a brain-region-specific manner in young-adult male rats: relevance to autism spectrum disorders. Int. J. Mol. Sci. 21, 3576 (2020).

193. Mukhopadhyay, S., Chatterjee, A., Tiwari, P., Ghai, U., Vaidya, V. A. Postnatal fluoxetine treatment alters perineuronal net formation and maintenance in the hippocampus. eNeuro 8, ENEURO.0424-20.2021 (2021).

194. Reincke, S. A. J. \& Hanganu-Opatz, I. L. Early-life stress impairs recognition memory and perturbs the functional maturation of prefrontal-hippocampalperirhinal networks. Sci. Rep. 7, 42042 (2017).

195. Guadagno, A. et al. Reduced resting-state functional connectivity of the basolateral amygdala to the medial prefrontal cortex in preweaning rats exposed to chronic early-life stress. Brain Struct. Funct. 223, 3711-3729 (2018).

196. Pezawas, L. et al. 5-HTTLPR polymorphism impacts human cingulateamygdala interactions: a genetic susceptibility mechanism for depression. Nat. Neurosci. 8, 828-834 (2005).

197. Heinz, A. et al. Amygdala-prefrontal coupling depends on a genetic variation of the serotonin transporter. Nat. Neurosci. 8, 20-21 (2005).

198. Rinaldi, T., Kulangara, K., Antoniello, K. \& Markram, H. Elevated NMDA receptor levels and enhanced postsynaptic long-term potentiation induced by prenatal exposure to valproic acid. Proc. Natl Acad. Sci. U.S.A. 104, 13501-13506 (2007).

199. Rinaldi, T., Silberberg, G. \& Markram, H. Hyperconnectivity of local neocortical microcircuitry induced by prenatal exposure to valproic acid. Cereb. Cortex $\mathbf{1 8}$, 763-770 (2008).

200. Graciarena, M., Seiffe, A., Nait-Oumesmar, B. \& Depino, A. M. Hypomyelination and oligodendroglial alterations in a mouse model of autism spectrum disorder. Front. Cell. Neurosci. 12, 517 (2018).
201. Levine, A., Worrell, T. R., Zimnisky, R. \& Schmauss, C. Early life stress triggers sustained changes in histone deacetylase expression and histone $\mathrm{H} 4$ modifications that alter responsiveness to adolescent antidepressant treatment. Neurobiol. Dis. 45, 488-498 (2012).

202. Hill, D. S. et al. Autism-like behavior and epigenetic changes associated with autism as consequences of in utero exposure to environmental pollutants in a mouse model. Behav. Neurol. 2015, 426263 (2015).

203. Choi, C. S. et al. The transgenerational inheritance of autism-like phenotypes in mice exposed to valproic acid during pregnancy. Sci. Rep. 6, 36250 (2016).

204. Lieb, M. W. et al. Effects of maternal separation on serotonergic systems in the dorsal and median raphe nuclei of adult male Tph2-deficient mice. Behav. Brain Res. 373, 112086 (2019).

205. Houwing, D. J., Ramsteijn, A. S., Riemersma, I. W. \& Olivier, J. D. A. Maternal separation induces anhedonia in female heterozygous serotonin transporter knockout rats. Behav. Brain Res. 356, 204-207 (2019).

206. Houwing, D. J. et al. Perinatal fluoxetine treatment and dams' early life stress history alter affective behavior in rat offspring depending on serotonin transporter genotype and sex. Behav. Brain Res. 392, 112657 (2020).

207. van der Doelen, R. H. A., Kozicz, T. \& Homberg, J. R. Adaptive fitness; early life adversity improves adult stress coping in heterozygous serotonin transporter knockout rats. Mol. Psychiatry 18, 1244-1245 (2013).

208. Gartstein, M. A. et al. Sculpting infant soothability: the role of prenatal SSRI antidepressant exposure and neonatal SLC6A4 methylation status. Dev. Psychobiol. 58, 745-758 (2016).

209. Veenstra-VanderWeele, J. et al. Autism gene variant causes hyperserotonemia, serotonin receptor hypersensitivity, social impairment and repetitive behavior. Proc. Natl Acad. Sci. U.S.A. 109, 5469-5474 (2012).

210. Siemann, J. K. et al. An autism-associated serotonin transporter variant disrupts multisensory processing. Transl. Psychiatry 7, e1067 (2017).

211. Rotem-Kohavi, N. et al. Hub distribution of the brain functional networks of newborns prenatally exposed to maternal depression and SSRI antidepressants. Depress. Anxiety 36, 753-765 (2019).

212. Nomura, Y. et al. Influence of in utero exposure to maternal depression and natural disaster-related stress on infant temperament at 6 months: the children of Superstorm Sandy. Infant Ment. Health J. 40, 204-216 (2019).

213. Coste, J. et al. Risk of early neurodevelopmental disorders associated with in utero exposure to valproate and other antiepileptic drugs: a nationwide cohort study in France. Sci. Rep. 10, 17362 (2020).

214. Zhou, X. et al. Behavioral training reverses global cortical network dysfunction induced by perinatal antidepressant exposure. Proc. Natl Acad. Sci. U.S.A. 112 2233-2238 (2015) 